\title{
Tanzimat Dönemi Cizye Defterlerine Göre Antalya Gayrimüslimleri
}

\author{
Non-Muslims in Antalya in the Tanzimat Period from the Poll Tax Registers
}

\begin{abstract}
Güven DİNÇ *
Öz: Cizye defterleri Osmanlı Devleti’nde gayrimüslimlere münhasır kayıtlardandır. Tanzimat dönemine dair tespit edilen sekiz adet cizye defterine göre Antalya'da gayrimüslimler yerli Rumlar ve Ermeniler, yabancı Rum, Ermeni ve Yahudilerden müteşekkildi. Yerli gayrimüslim miktarı 2800 civarında olup, bu şehir merkezinin üçte birine yakın bir orandı. Antalyalı gayrimüslimlerde hane nüfusu kadınlar da dâhil edildiğinde ortalama 5 kişiydi. Yaş ortalamaları oldukça genç ve dinamik bir yapıdadır. Bu sebeple çalışabilirlik ve vergilendirme açısından verimli bir durum söz konusudur. Gayrimüslimlerin meslekleri ve kullandıkları isimler Osmanlı toplumundaki geleneksel yapılarıyla uyumludur.
\end{abstract}

Anahtar sözcükler: Antalya, Gayrimüslim, Cizye, Tanzimat, Osmanlı

Abstract: Poll-tax registers are exclusive to the non-Muslim peoples in the Ottoman State. According to eight poll-tax registers dating from the Tanzimat period, both native and foreign non-Muslims lived in Antalya. The native non-Muslims were Greeks and Armenians, the foreigners were Greeks, Armenians and Jews. The number of native non-Muslims was around 2800, which is close to $1 / 3$ of the city centre population. If the women are included, the average household size of the non-Muslim population of Antalya was 5 persons. The age ratio was quite young and dynamic. For this reason, there was an efficient situation, in terms of ability to work and taxation. The professions and the names of the non-Muslims of Antalya are compatible with their traditional structures within Ottoman society..

Keywords: Antalya, Non-Muslims, Poll-Tax, Ottoman, Tanzimat

\section{Giriş}

Osmanlı dönemi sosyal ve ekonomi tarihi konuları son yıllarda artan bir şekilde çalışılmaktadır. $\mathrm{Bu}$ kapsamda üretilen yayınlarda kullanılan kaynaklar arasında şer'iyye sicilleri, nüfus ve temettuat defterleri başı çekmektedir. Bu kaynaklar hiç şüphesiz sosyal ve ekonomi tarihi araştırmalarında çok değerli veriler sunmakla birlikte özellikle gayrimüslimlerin yaşadıkları bölgelerde katkı sağlayabilecek cizye defterleri çoğu zaman göz ardı edilmektedir. Bu ise gayrimüslimler üzerinde yapılan/yapılacak değerlendirmelerin hatalı/eksik olmasına yol açabilmektedir. Ancak bu defterlerden gayrimüslimler hakkında derinlemesine bilgiler edinebilmek mümkündür (Özel 2000, 36-48). Cizye defterleri yerel kayıtlardan sayıldığından yapılacak çalışmaların da bu temelde olması gerekmektedir. Son yıllarda cizye defterleri temelli bir takım çalışmalar yapılmaya başlanmıştır (Erpolat 2003, 189-204; Özcoşar-Güneş 2006, 159-179; Dündar 2012, 99-122; Loklar 2012; Yörük 2013, 439-466; Şen 2014; Şen-Eken 2016, 47-66; 2016a, 161-175; 2016b, 105-132; Kocaoğlu 2017).

\footnotetext{
*Doç. Dr., Akdeniz Üniversitesi, Edebiyat Fakültesi, Tarih Bölümü, Antalya. gdinc@ akdeniz.edu.tr
} 
Gayrimüslimlerle ilgili en doğru bilgilerin yine gayrimüslimlere münhasır kayıtlardan elde edilebileceği düşüncesinden hareketle bu kayıtların kullanılması doğru bir yaklaşım olacaktır. Bu maksatla çalışmada cizye defterleri ş̧ı̆̆ında Tanzimat döneminde Antalya şehrinde (nefs-i Antalya) yaşayan gayrimüslimler konu edilmektedir. Bu vesile ile çalışmanın diğer bir amacı Osmanlı dönemi sosyal ve ekonomi tarihi çalışmalarında cizye defterlerinin önemine dikkat çekmektir.

Antalya tarihi henüz birçok bilinmezlerle doludur. Bunlardan önemli bir yönünü gayrimüslimler teşkil etmektedir. Antalya tarihi üzerine yapılan akademik çalışmalarda gayrimüslimler yeterince incelenmiş değildir (Teke sancağında gayrimüslimlerin yaşadığ 1 bir diğer kaza olan Elmalı kazası gayrimüslimleri bu ifadenin dışındadır. Elmalı kazası gayrimüslimleri ayrıntılarıyla incelenmiş durumdadır (Durgun 2014)). 19. yüzyıl ortalarında aile kurumu üzerine yapılan bir çalışmada (Dinç 2005a, 103-129) gayrimüslimlerle ilgili olarak şer'iyye sicilleri temelli sonuçlara ulaşılmıştır. Şer'iyye sicili transkripsiyonları ve değerlendirmelerinden oluşan yüksek lisans tezlerinde ise Antalya ile ilgili dönemine ait bulgular incelenen defterler özelinde paylaşılmaktadır (Beden 2004; Dinç 2005b; Taşbaş 2007; Tanrısever 2007; Tan 2010). Dolayısıyla şu ana kadar Antalya tarihi üzerine yapılan çalışmalarda cizye defterleri yeterince incelenmiş değildir.

Antalya MÖ II. yüzyıl ortalarında Bergama kralı II. Attalos zamanında kuruldu. Uzun süre Roma ve Doğu Roma hâkimiyetlerinde kalan şehir, Anadolu Selçuklu Devleti Sultanı Gıyaseddin Keyhüsrev zamanında 5 Mart 1207'de Türk hâkimiyetine girdi (Turan 2010, 305-307). Müslümanlarla (Türkler) Hristiyanların (Rumlar) (Antalya'da Türk tarihinin başlangıcından itibaren şehirdeki Müslüman nüfus büyük çoğunlukla Türklerdir. XIX. yüzyıl kaynaklarında Müslim/Müslüman tabiri kullanılsa da Antalya'daki Müslümanlardan kastedilenlerin Türkler olduğu; benzer şekilde gayrimüslimlerin de Rumlar olduğu bilinmelidir. Antalya'daki ilişkisi bu fetihle yoğunluk kazandı. Gayrimüslimlerin, fetihten sonra Antalya'ya yerleştirilen Müslümanları ortadan kaldırmaya girişmesi nedeniyle şehirdeki yerleşim planı ayrıştırıldı. 22 Ocak 1216 tarihinde şehrin ikinci kez fethinden sonra Müslümanlarla gayrimüslimlerin yaşadıkları mahalleler inşa edilen iç surlarla birbirinden ayrıldı. Böylece Hıristiyanlar şehrin doğusuna, Müslümanlar da batısına yerleştirildi (İbn-i Battuta 2004, 403; Durukan 1988, 28).

Osmanlı Devleti İslamiyet'in getirdiği kurallar (zimmet) çerçevesinde ülke sınırlarında yaşayan Müslüman olmayan topluluklar göz önünde bulundurularak kendisine özgü bir "millet sistemi" oluşturdu. Bu sistemde toplum ırki değil, dini açıdan (community) gruplara ayrılmıştır (Braude 1982, 69-70; Bozkurt 1989, 19-20). Yaklaşık yirmi farklı etnik gruptan oluşan Osmanlı gayrimüslimleri içerisinde en büyük yapıyı hiç şüphesiz Hıristiyanlar teşkil etmekteydi (Ercan 1999, 198-199).

Osmanlı Devleti'nde oluşan hukuki düzen ve yukarıda çizilen çerçeve dâhilinde Antalya'da yerleşen Müslümanlar ve gayrimüslimlerin farklı mahallelerde yaşaması ilkesi Osmanlı dönemi boyunca devam etti.

\section{Cizye Vergisi}

Cizye "kâfi gelmek; karşıllı̆ını vermek, ödemek" manasındaki ceza mastarından türemiş bir isim olup (Erkal 1993, 42), İslâm literatüründe gayrimüslim tebaanın "harb̂̋” olanlardan ayrı tutulmalarına, can ve mal güvenliğine kavuşturulmalarına karşılık ödedikleri vergidir (İnalcık 1960, 562; Ercan 1991, 371-381; Nedkoff 1944, 599-652). Osmanlı Devleti'nde 16. yüzy1la kadar bu vergiyi ifade etmek üzere "haraç" terimi kullanılmışsa da sonrasında "cizye" veya "cizye-i şer '’" deyimleri yerleşmiştir (İnalcık 1960, 562). Bu vergi her yıl baş üzerine konulduğundan "Başs 
Vergisi" olarak da anılmaktaydı (Nedkoff 1944, 608; Çağatay 1947, 494).

Cizye her yıl reşit yaşa (sinn-i rüşd) gelmiş 14-15 yaş ve üzeri erkek gayrimüslimlerden alınmaktaydı. Kadın ve çocuklar yanında bağışlarla geçinen rahipler, ihtiyar, köle, daimî hastalar ve dilenciler bu vergiden muaftılar. Dolayısıyla cizye bir nevi eli silah tutanları kapsamaktaydı. Cizye ödemekle mükellef biri İslamiyet'i kabul ettiği takdirde bu mükellefiyeti de ortadan kalkardı (Nedkoff 1944, 608-611).

Verginin oranı Halife Ömer döneminde getirilen ve Hanefi mezhebince düzenlenen mükelleflerin gelir durumuna göre 4, 2 ve 1 oranlarında "âlâ", "evsat" ve "ednâ" sinıflarına göre alınması usûlü Osmanlı Devleti'nde de kabul edilmekle birlikte paranın birim ve değer olarak değişmesi nedeniyle alınan vergi miktarları zaman zaman güncellendi (Nedkoff 1944, 606; Ercan 1991, 373).

Cizye vergisi sadece gayrimüslimlerin ödediği bir vergi olarak görünse de gayrimüslimlerin hemen hemen hiçbir gelir sağlamayan askerlik hizmetinden muaf tutulması nedeniyle her türlü tehlike ve gelir getirmeyen görevlerden korunmuş olarak güven içerisinde ticaret ve sanatla meşgul olduklarından iktisadî hayata egemen olmuşlardır. $\mathrm{Bu}$ ise gayrimüslimlerden alınan cizyenin meşruiyeti olarak gösterilmektedir (Ercan 1991, 372-373).

Osmanlı Devleti'nde cizye mükellefiyetleri ve cizye miktarı düzenli olarak defterlere kaydedilirdi. Cizye hazinenin önemli bir kalemi olduğundan toplanmasına itina gösterilirdi. Cizye, ilk dönemlerde hane başına veya grup olarak "ber-vech-i makt $\hat{u}^{\text {'" }}$ olarak uygulama bularak sabit bir miktar üzerinden tahsil olundu (İnalcık 1993, 46). Merkezi hazine adına tayin edilen görevlilerce (cizyedâr) toplanan cizye, zaman zaman iltizama verilmekle beraber uzun süre hane başına tahsil edildi. Bu uygulama 1691 yılına kadar sürdü. Bu tarihte köklü bir reform ile hane sistemi yerine belirli bir yaşa gelen tüm yetişkin erkek nüfustan tahsili kararlaştırılarak maktu sistem kaldırıld. Yeni sistemle birlikte herkesin sadece kendi vergisinden sorumlu olduğu belirtilip ödemeleri belgelemek üzere mükelleflere "kâğtt" veya "varak" denen bir belge verilmeye başlandı (İnalcık 1993, 46). Bu kâğıdın dikkatli bir şekilde saklanması, vergi memurlarının talebi üzerine gösterilmesi açısından önemliydi (Öztürk 2008, 98).

19. yüzyılda Osmanlı Devleti'nin içinde bulunduğu durum ve dış müdahaleler cizye uygulamasında bazı değişiklikleri zorunlu kıldı (Şener 1990, 113). II. Mahmut döneminde cizyenin toplanmasında suistimalleri ortadan kaldırmak ve hazine gelirlerini artırmak maksadıyla 26 Nisan 1834 (16 Zilhicce 1249) tarihinde "esnaf-ı selâse" miktarları yeniden belirlendi. Buna göre âlâ 60 (4), evsat 30 (2) ve ednâ 15 (1) kuruş olarak tespit edildi (Nedkoff 1944, 627).

Tanzimat'ın ilanından sonra Avrupalı devletlerin gayrimüslimler üzerindeki istek ve nüfuzları dikkate alınarak bu alandaki baskıyı azaltmak amaciyla 17 Mart 1841 tarihinde cizyenin "ale' $r$ rüus" tahsiline son verilerek patrikhaneler aracılığıyla "an-cemaatin" tahsili yoluna gidildi. Ancak sadaret makamında meydana gelen değişiklikler neticesinde Reşit Paşa'nın yerine gelen İzzet Paşa döneminde (1842) cizye tekrar eski usulde "ale'r-rüus" toplandı. Sonrasında Reşit Paşa'nın tekrar sadarete gelmesiyle yeniden "an-cemaatin" usule geçildi. Peşi sıra meydana gelen değişiklikler cizye reformlarından beklenen neticenin alınmasının önüne geçmiştir (Gölen 2003, 43-44).

Cizye, 1856 yılında Osmanlı tebaası arasında eşitlik prensibi getiren Islahat Fermanı ile kaldırıldı. Bununla birlikte gayrimüslimlerin de askerlik hizmeti yapmaları gerektiği ortaya çıkınca bunlardan belirli bir vergi alınmak suretiyle bu hizmetten muafiyetleri kararlaştırıldı (Gülsoy 2002, 87). Böylece kaldırılan cizye vergisi 7 Ağustos 1909'de umumî askerlik mecburiyetinin çıkarılmasına kadar "bedel-i askeri" adı altında mahiyet değiştirerek varlığını sürdürdü (Nedkoff 1944, 630). 


\section{Antalya Cizye Defterleri}

Cizye defterleri Osmanlı döneminde gayrimüslimlere münhasır tutulmuş ender kayıtlardan biridir. Bu defterler serisi Tanzimat döneminde daha sıklıkla tutulmuştur. Zira Gülhâhe Hatt-1 Hümayûn'un gereği olarak herkesin hal ve tahammülüne göre vergilendirilmesi gerekmekte, bu ise vergilerin düzenli biçimde kayıt altına alınmasını zorunlu kılmaktaydı. Bu dönemde yapılan cizye sayımları da Tanzimat'ın "âhâli-i memâlikden her ferdin emlâk ve kudretine göre bir vergi-i münâsib ta'yin olunarak ziyâde birşey alınmaması" (Düstûr, Tertib 1, Cilt 1, 4-5) iktizasından idi. Dolayısıyla cizye defterlerinin daha düzenli ve disiplinli tutulduğu dönem Tanzimat'in hemen sonrasina tarihlenmektedir.

BOA'da Maliye Nezareti Varidatından Cizye Muhasebesi (ML.VRD.CMH.d.) ve Kamil Kepeci (KK.d) tasniflerinde Antalya'ya ait 8 cizye defteri tespit edilmiştir. Bunlar 1843 (1259) (BOA., ML.VRD.CMH.d., 171), 1846 (H. 1262) (BOA., ML.VRD.CMH.d., 682), 1847 (1263) (BOA., ML.VRD.CMH.d., 733), 1848 (H. 1264) (BOA., ML.VRD.CMH.d., 926), 1848-49 (H. 1265) (BOA., ML.VRD.CMH.d., 1127), 1849-50 (H. 1266) (BOA., KK.d., 3899), 1850-51 (H. 1267) (BOA., ML.VRD.CMH.d., 1251), 1851-52 (H.1268) (BOA., ML.VRD.CMH.d., 1346) yıllarına aittir. $\mathrm{Bu}$ defterlerde Teke Sancă̆g'nda bulunan tüm ehl-i zimmet reâyânın cizye vergileri kayıtlıdır. Bu defterlere göre sancak genelinde gayrimüslimler Antalya ve Elmalı kazalarında bulunmaktadırlar. Bu çalışmada sadece Antalya kazasında (nefs-i Antalya) bulunan gayrimüslimler konu edilmiştir. Defterlerden 1849-50 (H. 1266) (BOA., KK.d., 3899) tarihli defterin yazıları çoğunlukla silik veya okunamaz durumdadır. Bu sebeple bu defterden istifade etme olanağı az oldu.

Defterlerin sayfa sayıları farklılık arz etmektedir. Örneğin 1259 tarihli defter 33 sayfa iken 1262 tarihli olan1 41 sayfadır. En kısa defter 19 sayfa ile 1268 tarihlidir. Defterler genel olarak Teke sancağında mevcut/na-mevcut ve yabancı (sancak dışı) gayrimüslimlerin cizye-i şer'iyye amacıyla deftere kaydedildiği şeklinde kısa bir açıklamayla başlamaktadır. Bu açıklamalar standart bir formda olmamakla birlikte içerik olarak birbirine benzemektedir. Örneğin 1259 tarihli defter;

"Teke sancağında kâ 'în ehl-i zimmet re 'âyânın işbu elli dokuz senesine mahsuben üzerlerine edâsı lâzım gelen cizye-i şer 'iyeleri esnâf-ı selâse i 'tibâriyle ma 'rifet-i şer'-i şerîf ve me 'mûrları ve kocabaşıları inzimâm-ı ma 'rifetleriyle cem've tahsîl olunan mebâliğin mikdârını mübeyyin ve sinn ve mevlüdleriyle helâk ve 'adem-i mevcûdlarını mübeyyin defteridir" (BOA.,ML.VRD. CMH.d., 171, 2) biçiminde bir açıklamayla başlamaktadır.

1268 tarihli defterde ise;

"Teke Sancağı'nda mütemekkin ehl-i zimmet re 'âyânın altmış sekiz senesine mahsûben müstehak olduklart cizye bedellerinin defteridir" (BOA., ML.VRD.CMH.d., 1346, 2) şeklinde bir girizgâh bulunmaktadır.

Antalya cizye defterlerinin sonları yetkili kişilerin mühürleriyle bitmektedir. Bu bazen sadece naib mührüdür. Örneğin 1846 (H. 1262) (BOA., ML.VRD.CMH.d., 682, 41), 1847 (1263) (BOA., ML.VRD.CMH.d., 733, 31), 1848 (H. 1264) (BOA., ML.VRD.CMH.d., 926, 26), 1848-49 (H. 1265) (BOA., ML.VRD.CMH.d., 1127, 25), 1849-50 (H. 1266) (BOA., KK.d., 3899, 33), 1850-51 (H. 1267) (BOA., ML.VRD.CMH.d., 1251, 29), 1851-52 (H.1268) (BOA., ML.VRD.CMH.d., 1346, 19) tarihli defterler sadece Antalya naibinin hatmiyle son bulurken, 1843 (1259) tarihli defter diğerlerinden farklı olarak 4 vücûh-1 belde, nakib, mütfü, nâîb, kaymakam, kocabaşı (Pavloz) ve metropolit vekilinin (İstirati) unvanları veya mühürleriyle hitam bulmaktadır (BOA., ML.VRD.CMH.d., 171, 33). 
Cizye defterlerinden 1843 tarihli defter 1840 tarihli Antalya gayrimüslim nüfus sayım defteri esas alınarak düzenlenmiştir (BOA., NFS.d., 3206). Dolayısıyla 1843 yılı cizye defterinde vergiye mükellef yaşta olup olmadığına bakılmaksızın bütün nüfus kaydedilmiştir. Bu aynı zamanda 1843 yılında Antalya'da gerçek bir cizye sayımının yapılmayıp, 1840 yılı nüfus defteri esas alınarak düzenlendiğinin de işaretidir. Bu yılki cizye sayımının gerçek bir sayım olmadığı 1840 tarihli nüfus defteri ile karşılaştırıldığında açık bir şekilde görülebilmektedir. 1840 yılı nüfus defterindeki kişiler 1843 yılı cizye sayımında da kayıtlıdır. Kaydedilen yaşlar da aynıdır. Cizye defterindeki fark üç yıl içerisinde vefat edenlerin ve şehir dışında bulunanlar var ise bunların gösterilmesinden ibarettir. 1843 yılı cizye defterine özgü taraflardan biri yabanciyan ve Kıptiyan nüfus ile alakalıdır. Bu hususlar 1840 tarihli nüfus sayım defterinde yoktur.

1843 y1lı cizye defterinde diğer yıllardan farklı olarak, mükellef olmayan çocukların da dâhil edilerek bütün nüfusun kaydedilmesinin gerekçesi ne olabilir? $\mathrm{Bu}$ sorunun cevabı Tanzimat'ın yukarıda işaret edilen temel hedeflerinin arasında yatmaktadır. 1840 yılından itibaren başlatılan nüfus, temettuat, cizye vb. sayımlar herkesin hal ve tahammülüne göre vergilendirilmesi amacını gütmekteydi. Bu maksatla Antalya'da gayrimüslimler için öngörülen cizye sayımları ilk kez 1843 tarihinde gerçekleştirilmiştir. Dolayısıyla kısa bir süre önce, 1840 yılında yapılan nüfus sayım defteri esas alınmak suretiyle çocuklar da dâhil edilip bütün nüfus kaydedilmiştir. Bu sayede gayrimüslim nüfusun cizye vergileri ve gelecek yıllardaki vergi potansiyeli ortaya çıkarılmıştır. Sonraki yıllarda çocukların sayıma dâhil edilmesine ihtiyaç duyulmamıştır.

\section{Antalya'da Bulunan Gayrimüslim Cemaatler}

Cizye sayımları gayrimüslimlere münhasır olduğundan defterlerde Antalya'da hangi gayrimüslim cemaatlerin bulunduğu açık biçimde tespit edilebilmektedir. Ayrıca bütün defterlerde yerli olmayıp sayım sırasında çeşitli nedenlerle Antalya'da bulunan gayrimüslimler (yabancıyân) de cizye evraklarını buradan almaları münasebetiyle kayıt altına alınmışlardır.

Döneme ait 8 deftere göre Antalya'da bulunan gayrimüslim cemaatler Rumlar, Ermeniler ve Yahudilerdi. Rumlar ve Ermeniler şehrin yerlisi (yerleşik) iken Yahudiler sadece çeşitli sebeplerle geçici olarak şehirde bulundukları için "yabancıyân" içerisinde kaydedilmişlerdir. Bu dönemde Antalya'da yerleşik Yahudi nüfus yoktu. Ayrıca büyük kısmını Rumların teşkil ettiği "yabancıyân" arasında bir miktar Ermeni de vardı.

Rum ve Ermeni cemaatlerinin liderleri cizye defterlerinde ilk sırada kaydedilmekteydi. Sözgelimi 1846 tarihli defterde Rum cemaatin lideri bulunan Papas Dimitri veled-i Agabi ilk sırada kayıtlıydı (BOA., ML.VRD.CMH.d., 682, 2). Ermenilerde ise herhangi bir dini görevli olmadığından en yaşlı olan kişiler ilk sırada bulunmaktadırlar. Aynı tarihli defterde Ermeni cemaatinin en yaşlı (57) üyesi olan Esir veled-i Agob ilk sırada bulunuyordu (BOA., ML.VRD. CMH.d., 682, 25).

Cizye defterlerinde Rumlar ve Ermeniler dışında Kıpti (İslâm) Kazgancıyan cemaati de kaydedilmiştir (BOA., ML.VRD.CMH.d., 171, 25-26). Kıptilerden kasıt Çingenelerdir. Çingenelerin Mısır'dan neşet ettiği kabul edilerek bunlara Kıpti denilmiştir (Gökbilgin 1988, 421). Kıptiler Müslüman ya da gayrimüslim olabilmekteydi (Altınöz, 2013). Kıptiler ister Müslüman, ister gayrimüslim olsun cizye vergisi mükellefiydiler. Antalya'daki Kıptiler de bu bağlamda Müslüman (İslâm) olup cizye vergisine tâbiydiler. Müslüman adları bulunan Antalyalı Kıptilerin başında "Çeribaşı" bulunmaktaydı. Çeribaşı olan kişi cizye defterlerinde ilk sırada kaydedilmekteydi (BOA., ML.VRD.CMH.d., 171, 25). Kıptiler gayrimüslim cemaat içerisinde değerlendirilmemekle birlikte cizyeye tabi olmaları sebebiyle bu çalışmanın cizye vergisi hesaplamalarına dâhil edilmiştir. 


\section{Gayrimüslimlerin Yaşadıkları Mahalleler}

Cizye defterleri cemaatlere göre ayrılmasının yanında bunların hangi mahallelerde yaşadıkları da açık biçimde kaydedilmektedir. Ancak gayrimüslimlerin ikamet ettiği mahallelerle ilgili olarak sadece yerleşik unsurlar hakkında bilgi verilmiştir. Cizye defterlerine göre Antalya yerleşik gayrimüslim cemaatinden Rumlar Cami-i Cedid, Baba Doğan ve Makbûle mahallelerinde yaşamaktaydı. Yerleşik Ermeniler ise kendi adlarıyla (Mahalle-i Ermeniyân) anılan mahallede kaydedilmişlerdir. "Ermeniyân Mahallesi" ayrı bir mahalle olmayıp Baba Doğan mahallesinin bir parçası idi. Bu adlandırma Ermenilerin toplu bir şekilde kaydedilmesinin pratik şeklinden başka bir şey değildi. Ancak anlaşıldığı kadarıyla az sayıdaki Ermeniler Baba Doğan mahallesinde toplu halde yaşamaktaydılar. Yerleşik Rumlar ve Ermeniler haricinde Antalya'ya ticaret, misafirlik vb. amaçlarla gelen Rum, Ermeni, Yahudi ve Kıptilerin ise nerede yaşadıkları kaydedilmemekle birlikte bir kısmının daha çok kale dışındaki hanlarda ikamet ettikleri kesindir. Misafirlik amacıyla gelenler ise arkadaşları veya akrabalarının yanlarında bulundukları varsayılırsa kale içerisindeki mahallelerde idiler (BOA., ML.VRD.CMH.d., 171, 2-25).

Defterlerde Antalyalı yerli gayrimüslimlerin yaşadıkları mahallelerin kayıt düzeni şöyledir: İlk olarak Cami-i Cedid, ikinci sırada kayıtlı olanı Baba Doğan ve üçüncü sırada Makbule mahalleleri kayıtlıdır. Sadece 1849-50 (1266) (BOA., KK.d., 3899) ve 1850-51 (1267) (BOA., ML.VRD.CMH.d., 1251) tarihli defterlerde ikinci sırada Makbule, üçüncü sırada Baba Doğan mahalleleri sıralanmıştır. Bu husus mahallelerin alan ya da nüfus büyüklükleri ile alakalı olmayıp kâtiplerin tercihleridir. Ancak Cami-i Cedid mahallesi bütün defterlerde öncelikle kaydedilmektedir. Bunun gerekçesi ise belirtildiği üzere Rum cemaatinin liderinin bu mahallede yaşayıp ilk sırada kaydedilmesidir.

\section{Gayrimüslim Nüfus Miktarı}

Osmanlı Devleti'nde modern anlamda bir nüfus sayımının yapılması askerî ve ekonomik maksatlarla 19. yüzyılda gündeme geldi. Bu anlamda ülke genelinde uygulanan ilk sayım 1830-1831 [1246] yılında gerçekleştirildi. Osmanlı yönetimi bu sayımla, Müslim ve gayrimüslim nüfusu tespit etmeyi, böylece askere alınabilecek Müslüman ve cizye mükellefi gayrimüslim erkek nüfusu belirlemeyi amaçladı (Karal 1943, 10-12). Diğer bir nüfus sayımı 1840-1844 yıllarında gerçekleştirildi. Bu defa yapılan sayımlar Tanzimat-1 Hayriye'nin bir ürünüydü.

Öte yandan aynı amaca yönelik olarak gayrimüslimler için doğrudan cizye sayımları da yapıldı. Başbakanlık Osmanlı Arşivi'nde Tanzimat'ın hemen sonrasına tarihlenen pek çok sancak ve vilayete ait çok sayıda cizye defteri mevcuttur. Dolayısıyla yaklaşık aynı tarihlerde yapılan nüfus ve cizye sayımlarının temel amacı gayrimüslim nüfusun cizye vergisi yönünden tanımlanmasından ibaretti. Nüfus sayımlarında da cizye mükellefi olanların âlâ, evsat ve ednâ olarak kaydedilmiş olması bunu teyit etmektedir. Sonuç olarak bu dönemde nüfus ve cizye sayımları aynı hedef doğrultusunda yapıldığından içerik olarak da benzerdir. Dolayısıyla cizye sayımlarından Antalya gayrimüslim nüfusun tespiti nüfus sayım defterleri oranında mümkün olabilmektedir. Diğer bir deyişle bu dönemin bütün gayrimüslim erkek nüfusun kaydedildiği cizye defterlerini "nüfus defteri" olarak da saymak gerekmektedir.

İncelenen cizye defterleri içerisinde Antalya'da bulunan bütün gayrimüslim nüfusun (erkek) kaydedildiği tek defter 1843 (H. 1259) tarihlidir (BOA., ML.VRD.CMH.d., 171). Bu defter 1840 tarihli nüfus sayım defterine (BOA., NFS. d., 3206) dayanılarak oluşturulmuştur. Diğer defterlerde sadece vergiye mükellef olabilecek yaştaki (14 ve üzeri) nüfus kaydedilmiş, çocuklara (sabî) yer verilmemiştir.

Cizye defterlerinde, 1843 yılı defteri hariç, hane sayıları numaralandırılmıştır. Mahallelerde 
bulunan haneler bir numaradan başlanarak son haneye kadar sayılmışlardır. Hane içerisinde cizye mükellefi olan kimse yoksa, bu haneler numarası atlanmak suretiyle gösterilmişlerdir. Dolayısıyla böyle hanelerdeki nüfus bilinememektedir. Son hanenin numarasına bakıldığında mahalledeki toplam hane sayısı ortaya çıkmaktadır. Hane numarası yanında kayıtlı hanelerdeki mükellef nüfus da sayılmışlardır. Hane içerisindeki nüfus sayımı sırasında mükellefiyetten düşürülenler var ise onların numaraları atlanarak gösterilmişlerdir. Hane içerisindeki son kişinin sıra numarası hanedeki kişi sayısını göstermektedir. Bu sayede defterlerde bütün nüfus kaydedilmese dahi kayıtlı hanelerde çocuklar dışında kalan tüm nüfusu tespit edebilmek mümkündür.

1843 tarihli cizye defterinde ise hane numaraları kayıtlı değildir. Hane numarası gösterilmemekle birlikte her mahalle girişinde bir numaradan başlanarak bireylere sıra numaraları verilmiş ve sayılmışlardır. Bu sayede hane sayısı olmasa bile çocukların da dâhil olduğu toplam nüfus açık biçimde görülebilmektedir.

Bu kayıt usullerine göre 1843 tarihli cizye defterinde Antalya gayrimüslim nüfusuna dair ortaya çıkan veriler şu şekildedir:

Tablo 1. 1843 (H. 1259) Cizye Sayımına Göre Antalya'da Bulunan Gayrimüslimler (Yabancilar Dâhil)

\begin{tabular}{|l|c|c|c|c|c|}
\hline & $\begin{array}{c}\text { Cami-i Cedid } \\
\text { Mahallesi }\end{array}$ & $\begin{array}{c}\text { Makbûle } \\
\text { Mahallesi }\end{array}$ & $\begin{array}{c}\text { Baba Doğan } \\
\text { Mahallesi }\end{array}$ & $\begin{array}{c}\text { İkamet Yeri } \\
\text { Bilinmiyor }\end{array}$ & Toplam \\
\hline Yerli Rum & 510 & 393 & 359 & & 1262 \\
\hline Yerli Ermeni & & & 17 & & 17 \\
\hline Yabanc1 Rum & & & & 59 & 148 \\
\hline Yabanc1 Ermeni & & & 376 & 207 & 1486 \\
\hline Toplam & 510 & 393 & & & \\
\hline
\end{tabular}

Kaynak: BOA., ML.VRD.CMH.d., 171, 2-33.

1843 yılı cizye defterine göre - bu defter 1840 yılı nüfus sayımı verileri esas alınarak düzenlenmiştir - Cami-i Cedid mahallesinde 510, Makbule mahallesinde 393, Baba Doğan mahallesinde 376 kişi vardı. Baba Doğan mahallesinin 17'si Ermeni olup, bunların tamamı yerli idi. Şehrin neresinde yaşadıkları bilinmeyen Yabancıyan Rumlar ve Ermeniler ise 207 kişiydi. Yerli Rum ve Ermenilerin toplamı 1279 kişiydi. Yabancılarla birlikte şehirde toplam 1486 gayrimüslim nüfus bulunmaktaydı.

Mahallelerin nüfus açısından büyüklüklerine bakıldığında Cami-i Cedid mahallesi bariz biçimde ilk sıradadır. Makbule ve Baba Doğan mahallelerinin nüfusları ise birbirine oldukça yakındı. Aslında Baba Doğan mahallesinin Rum nüfusu Makbule mahallesine göre belirli oranda az (34) olsa da bu mahalledeki Ermeni nüfus (17) aradaki farkı kapatmıştır.

Ermeniler Baba Doğan mahallesinin sadece \% 4,5'ini, şehirdeki bütün yerli gayrimüslim nüfusun \% 1,3'ünü teşkil etmekteydi. Özetle şehirde kendisini hissettirecek düzeyde bir Ermeni nüfusun varlığından söz etmek zordur. Yabancı nüfus verileri aşağıda ayrıntılı olarak ele alınacağından burada sadece nüfus sayılarının nicelik olarak verilmesiyle yetinilmektedir.

1843 tarihli defterde hane sayısı gösterilmese de en yakın tarihli olan 1846 yılı defterine göre Antalya Rumlarına ait toplam 575 hane vardı. Buna göre mahallelerde hane başına düşen nüfus şöyledir: 
Tablo 2. 1843 Yılı Cizye Defterine Göre Yerli Gayrimüslim Nüfus

\begin{tabular}{|l|c|c|c|}
\hline Mahalleler & Nüfus & Hane Miktarı & Hane Başına Düşen Nüfus \\
\hline Cami-i Cedid & 510 & 233 & 2,19 \\
\hline Baba Doğan & 359 & 174 & 2,06 \\
\hline Makbûle & 393 & 159 & 2,47 \\
\hline Ermeniyan & 17 & 9 & 1,89 \\
\hline Toplam & 1279 & 575 & 2,22 \\
\hline
\end{tabular}

Kaynak: BOA., ML.VRD.CMH.d., 171, 2-25.

1843 yılı cizye sayımı çocukların da kaydedildiği tek cizye defteri olması açısından önemlidir. $\mathrm{Bu}$ defterdeki verilere göre Antalya'daki çocuk sayısı Cami-i Cedid mahallesinde 134, Makbûle mahallesinde 108, Baba Doğan mahallesinde 102, Ermeniyan'da 5 olmak üzere toplam 349 idi (BOA., ML.VRD.CMH.d., 171, 2-25). Çocuk nüfus çıkarıldığında geriye 930 kişilik bir nüfus kalmaktadır. Buna göre yerli nüfusun \% 27,28'lük nispeti çocuklardan oluşmaktaydı. Yabancı nüfus içerisinde sadece vergi mükellefleri sayıldığından çocuklar kaydedilmemişlerdir.

Aynı tarihli defterde Rumlar ve Ermeniler haricinde Müslüman olmalarına rağmen cizye mükellefi sayıldıklarından kaydedilen Müslüman Kıpti miktarı (Kıpti Kazgancıyân) ise 59 kişiydi. Ancak bunları gayrimüslim nüfus içerisinde değerlendirmek yanlıştır. Diğer cizye defterlerinden elde edilen nüfus verileri ise şöyleydi:

Tablo 3. Cizye Defterlerine Göre Antalya'da Yerli Gayrimüslim Nüfus Miktarı (1846-1852)

\begin{tabular}{|c|c|c|c|c|c|c|c|c|c|c|c|c|}
\hline \multirow{2}{*}{ Mahalleler } & \multicolumn{6}{|c|}{$\begin{array}{c}\text { Mükellef Bulunup Kaydedilen } \\
\text { Hane Miktarı }\end{array}$} & \multicolumn{6}{|c|}{ Toplam Gösterilen Hane Sayısı } \\
\hline & 1846 & 1847 & 1848 & $\begin{array}{l}1848- \\
1849\end{array}$ & $\begin{array}{l}1850- \\
1851\end{array}$ & $\begin{array}{l}1851- \\
1852\end{array}$ & 1846 & 1847 & 1848 & $\begin{array}{l}1848- \\
1849\end{array}$ & $\begin{array}{l}1850- \\
1851\end{array}$ & $\begin{array}{l}1851- \\
1852\end{array}$ \\
\hline Cami-i Cedid & 221 & 214 & 212 & 217 & 229 & 215 & 233 & 233 & 233 & 236 & 239 & 239 \\
\hline Baba Doğan & 160 & 158 & 159 & 164 & 172 & 161 & 174 & 174 & 175 & 181 & 181 & 181 \\
\hline Makbûle & 157 & 153 & 150 & 171 & 174 & 167 & 159 & 159 & 159 & 179 & 180 & 180 \\
\hline Ermeniyan & 9 & 8 & 8 & 5 & 5 & 5 & 9 & 9 & 9 & 6 & 6 & 6 \\
\hline Toplam & 547 & 533 & 529 & 557 & 580 & 548 & 575 & 575 & 576 & 602 & 606 & 606 \\
\hline Mahalleler & \multicolumn{6}{|c|}{ Kayıtlı Hanelerdeki Nüfus Miktarı } & \multicolumn{6}{|c|}{ Hane Başına Düşen Nüfus } \\
\hline Cami-i Cedid & 1846 & 1847 & 1848 & $\begin{array}{l}1848- \\
1849\end{array}$ & $\begin{array}{l}1850- \\
1851\end{array}$ & $\begin{array}{l}1851- \\
1852\end{array}$ & 1846 & 1847 & 1848 & $\begin{array}{l}1848- \\
1849\end{array}$ & $\begin{array}{l}1850- \\
1851\end{array}$ & $\begin{array}{l}1851- \\
1852\end{array}$ \\
\hline Baba Doğan & 374 & 361 & 378 & 394 & 435 & 426 & 1,69 & 1,69 & 1,78 & 1,82 & 1,9 & 1,98 \\
\hline Makbûle & 273 & 271 & 269 & 281 & 282 & 277 & 1,71 & 1,72 & 1,69 & 1,71 & 1,64 & 1,72 \\
\hline Ermeniyan & 310 & 298 & 307 & 286 & 293 & 286 & 1,97 & 1,95 & 2,05 & 1,67 & 1,68 & 1,72 \\
\hline \multirow[t]{2}{*}{ Toplam } & 11 & 10 & 11 & 9 & 9 & 8 & 1,22 & 1,25 & 1,38 & 1,8 & 1,8 & 1,6 \\
\hline & 968 & 940 & 965 & 970 & 1019 & 997 & 1,77 & 1,76 & 1,82 & 1,74 & 1,76 & 1,72 \\
\hline
\end{tabular}

Tablodan anlaşılacağı üzere 19. yüzyıl ortalarında Antalya yerli gayrimüslimlerinin hane say1ları yüzyılın ikinci yarısına geçirilirken 600'ün üzerine çıkmıştı. Hane sayısının kısa sürede 575'ten 606'ya kadar çıkması gayrimüslimlerin aynı mahallelerde yaşayan Müslümanlardan ev satın alarak yaşam alanlarını genişlettiklerine işaret etmektedir.

Hane sayısının en fazla olduğu Cami-i Cedid mahallesi 1843 cizye sayımında da belirtildiği 
üzere gayrimüslimlerin en fazla yaşadıkları mahalleydi. Bu mahalledeki hane sayısı 239'a kadar yükselmiştir. Baba Doğan ve Makbule mahallelerinin hane sayıları ise yüzyılın ikinci yarısına geçirilirken birbirine yakındı. Ermeni hane sayısı ise azalmıştı. Bu ise Antalya Ermenilerinin şehirdeki geçmişlerinin çok eskilere dayanmadığının ve diğer bölgelerdeki Ermenilerden yeterince beslenemediklerinin en önemli işareti sayılmalıdır. Ermenilerin Antalya'ya ne zaman geldikleri tam olarak bilinemese de olasılıkla 18. yüzyılın ikinci yarısında geldikleri varsayılmaktadır (Sami 2012, 20-21).

18. yüzyıl ortalarına doğru Antalya yerli gayrimüslim nüfusunda, çocuklar ve kadınlar dışarıda bırakıldığında, genel olarak bir artış yaşandığı söylenebilir. Çocukların sayılmadığ 1 cizye kayıtlarına 1843 tarihli cizye sayımından tespit edilen yaklaşık \% 27,28'lik erkek çocuk oranı da eklenirse erkek gayrimüslim nüfus 1400 'lere, kadınların da dâhil edilebileceği hesaplamalara göre ise toplam gayrimüslim nüfus 2800'ün üzerine çıkmaktadır.

Tablo 4. Cizye Defterlerine Göre Antalya Yerli Gayrimüslim Nüfusu (1843-1852)

\begin{tabular}{|c|c|c|c|c|c|c|c|c|c|c|c|}
\hline \multirow[b]{2}{*}{ Y11 } & \multicolumn{2}{|c|}{ Cami-i Cedid } & \multicolumn{2}{|c|}{ Baba Doğan } & \multicolumn{2}{|c|}{ Makbûle } & \multicolumn{2}{|c|}{ Ermeniyan } & \multicolumn{2}{|c|}{ Toplam } & \multirow[b]{2}{*}{$\begin{array}{c}\text { Kadınlar } \\
\text { Dâhil Nüfus } \\
\text { Toplam }\end{array}$} \\
\hline & 亲 & 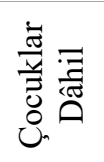 & 亲. & 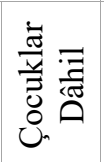 & 竞 & 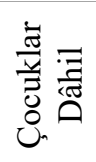 & 离. & 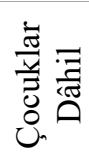 & 㝴. & 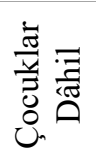 & \\
\hline 1843 (1259) & 376 & 510 & 257 & 359 & 285 & 393 & 12 & 17 & 930 & 1279 & 2558 \\
\hline $1846(1262)$ & 374 & 514 & 273 & 375 & 310 & 426 & 11 & 15 & 968 & 1331 & 2662 \\
\hline 1847 (1263) & 361 & 496 & 271 & 373 & 298 & 410 & 10 & 14 & 940 & 1293 & 2585 \\
\hline 1848 1264) & 378 & 520 & 269 & 370 & 307 & 422 & 11 & 15 & 965 & 1327 & 2654 \\
\hline $1848-49(1265)$ & 394 & 542 & 281 & 386 & 286 & 393 & 9 & 12 & 970 & 1334 & 2668 \\
\hline $1250-51(1267)$ & 435 & 598 & 282 & 388 & 293 & 403 & 9 & 12 & 1019 & 1401 & 2803 \\
\hline $1251-52(1268)$ & 426 & 586 & 277 & 381 & 286 & 393 & 8 & 11 & 997 & 1371 & 2742 \\
\hline
\end{tabular}

Gayrimüslimlerin kaydedildikleri hane sayılarının yükselişi aynı zamanda bir nüfus artışına da işaret etmektedir ki bu tablo ve grafiklerden açık biçimde izlenebilmektedir. 1840 y1lı nüfus sayımında Antalya gayrimüslim nüfusu 1283 kişi idi (BOA., NFS. d., 3206, 40). Cizye defterlerinden elde edilen rakamlar nüfus sayımıyla uyumlu olup ilerleyen yıllarda nüfusun artığına da işaret etmektedir. Aynı tarihli Müslüman nüfus kaza merkezindeki 3.132 erkek ve tahminî olarak 6.264 kişiydi (BOA., NFS. d., 3205). Buna göre Antalya şehir merkezinin (kale içi ve kale dışı mahalleleri) \%28-29'u gayrimüslimlere aitti. Bu rakama yabancıyan gayrimüslim nüfus da eklenirse oran bir miktar daha artmaktadır.

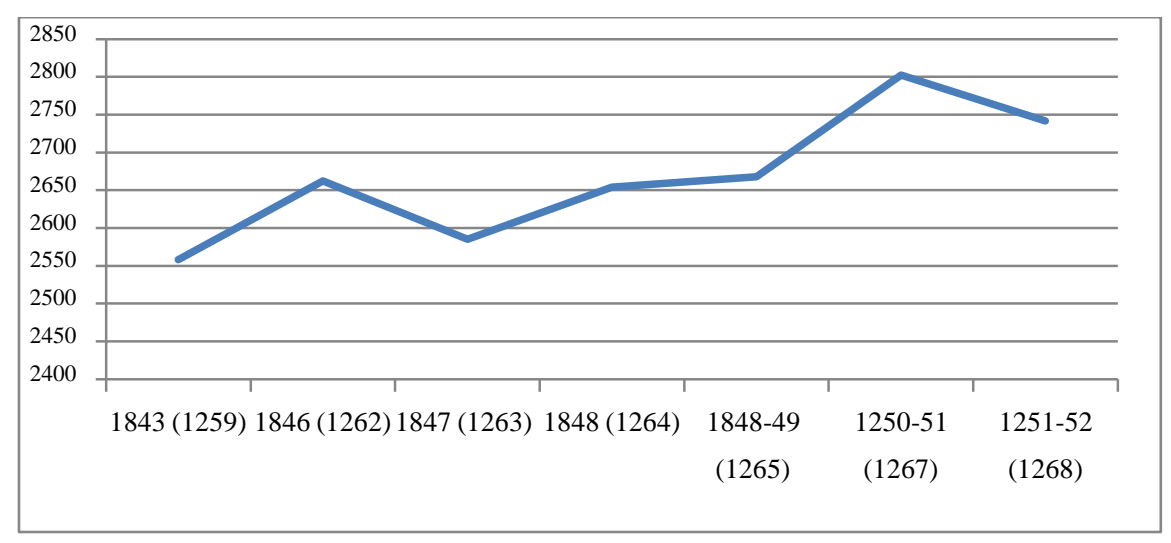

Grafik 1. Cizye Defterlerine Göre Antalya Yerli Gayrimüslim Nüfusu (1843-1852) 


\section{"Diyar-ı Ahar"a Giden Gayrimüslimler}

Antalyalı gayrimüslimlerden muhtelif nedenlerle başka şehirlere gidenler de olabilmekteydi. Bu bazen devlet görevi amacıyla, örneğin tersane-i amire hizmeti için, bazen de ticaret, misafirlik, göç vb. nedenlerle olabilmekteydi. Bu durumda bulunanların kayıtlarının üzerinde ilgili açıklamaları yapılmıştır.

1843 yılı cizye defterinde Antalyalı gayrimüslimlerden 62'si $(\% 4,86)$ sayım sırasında "diyâr-ı âharda", yani başka şehirlerde idi (BOA., ML.VRD.CMH.d., 171, 2-25).

1848-49 (1265) y1linda ise sayım sirasında 40 kişi şehir dışındaydı veya başka şehirlerden yeni gelmişti. Şehir dışında bulunma gerekçelerine bakıldığında 24'ü ticaret amacıyla gitmişti. Ticaret için yola çıkılan şehirlerarasında İskenderiye 6, İstanbul 3, Kıbrıs 3 kişi ile başı çekmekteydi. Şehir dışına ticaret amacıyla çıkanların yaşlarına bakıldığında 14 ila 55

\begin{tabular}{|l|c|}
\hline \multicolumn{2}{|l|}{ Tablo 5. 1843 (H. 1259) Cizye Sayımına Göre Antalyalı } \\
Gayrimüslimlerden Diyar-1 Âharda Bulunanlar \\
\hline Mahalleler & Diyar-ı Aharda Bulunanlar \\
\hline Cami-i Cedid & 29 \\
\hline Baba Doğan & 15 \\
\hline Makbule & 13 \\
\hline Ermaniyan & 5 \\
\hline Toplam & 62 \\
\hline
\end{tabular}
arası bir profil ortaya çıkmaktadır. Yaş ortalaması ise 30,9 idi (BOA., ML.VRD.CMH.d., 1127, 2-17). Bu ise şehir dışında ticaret amacıyla bulunan gayrimüslimlerin oldukça genç ve dinamik bir yapıda olduklarını göstermektedir. Şehirler arası ticareti ailecek yapanlar da vardı. Sözgelimi David v. Nikola ticaret maksadıyla Kıbrıs'a gittiğinde oğlu Dimitri de aynı dönemde İskenderiye'ye yönelmişti. Benzer şekilde Todoruz v. Dimitri aynı maksatla Kıbrıs'a gittiğinde oğlu Dimitri de Elmalı'ya hareket etmişti.

Tablo 6. 1848-49 (1265) Y1lında Diyar-1 Ahar'daki Antalyalı Gayrimüslimler

\begin{tabular}{|l|l|l|c|c|c|}
\hline & Adı & Nereye Gittiği & Yaşı & $\begin{array}{c}\text { Hangi Amaçla } \\
\text { Gittiği }\end{array}$ & $\begin{array}{c}\text { Hangi Yıl } \\
\text { Gittiği }\end{array}$ \\
\hline 1. & İstefan v. Kirye & Der-i Aliyye & 26 & Ticaret & 1259 \\
\hline 2. & David v. Nikola & Kıbrıs & 45 & Ticaret & - \\
\hline 3. & $\begin{array}{l}\text { Nikola v. David } \\
\text { (David v. Nikola'nın oğlu) }\end{array}$ & İskenderiye & 22 & Ticaret & - \\
\hline 4. & Anaştaş v. Anton & İzmir & 21 & Ticaret & - \\
\hline 5. & Anaştaş v. Eftim & Alaiye & 29 & Ticaret & - \\
\hline 6. & Yani v. Vasili & İzmir & 31 & Ticaret & - \\
\hline 7. & Anaştaş v. Ligori & Menteşe Sancağı & 22 & Ticaret & - \\
\hline 8. & Dimitri v. Mabed & Menteşe Sancağı & 18 & Ticaret & - \\
\hline 9. & İstirati v. Nikola & Elmalı'ya gidip gelmiştir & 50 & - & - \\
\hline 10. & Anaştaş v. Nikola & Elmalı'ya gidip gelmiştir & 34 & - & - \\
\hline 11. & Kostandi v. Sava & Diyar-1 Aharda & 16 & - & - \\
\hline 12. & Sava v. Manul & Firar edip ne tarafa gittiği & 35 & Firar & - \\
\hline & & bilinmemektedir & & & - \\
\hline 13. & Yakomi v. Nikola & İskenderiye & 19 & Ticaret & - \\
\hline 14. & Nikola v. Vasili & Elmalı'ya gidip gelmiştir & 36 & - & - \\
\hline 15. & Yani v. Vasili & Elmalı'ya gidip gelmiştir & 23 & - & - \\
\hline 16. & Vasili v. Kostandi & İskenderiye & 45 & Ticaret & - \\
\hline 17. & Todoruz v. Kirye & Elmalı'ya gidip gelmiştir & 26 & - & - \\
\hline 18. & Kirye v. İstoki & Elmalı'ya gidip gelmiştir & 25 & - & \\
\hline
\end{tabular}




\begin{tabular}{|c|c|c|c|c|c|}
\hline 19. & Yani v. Kobi & Hamid Sancağı & 22 & Ticaret & - \\
\hline 20. & Todoruz v. Dimitri & Kibris & 55 & Ticaret & - \\
\hline 21. & $\begin{array}{l}\text { Dimitri v. Todoruz Todoruz } \\
\text { v. Dimitri'un oğlu) }\end{array}$ & Elmalı & 18 & Ticaret & - \\
\hline 22. & İstoroz v. Anaştaş & Alaiye & 40 & Ticaret & - \\
\hline 23. & Mihail v. Yuriyi & Kibris & 55 & - & - \\
\hline 24. & Ligori v. Solomon & Girit & 23 & Ticaret & - \\
\hline 25. & Yuriyi v. Anton & Alaiye & 40 & Ticaret & - \\
\hline 26. & Atnas v. Anton & Meis Adası & 30 & Ticaret & - \\
\hline 27. & Nikola v. Arslan & İskenderiye & 34 & Ticaret & - \\
\hline 28. & Yani v. İstavri & Firari & 40 & Firar & - \\
\hline 29. & Kostandi v. Nikola & Elmalı'ya gidip gelmiştir & 26 & - & - \\
\hline 30. & Vasili v. Luka & Elmalı'ya gidip gelmiştir & 28 & - & - \\
\hline 31. & Anaştaş v. Luka & Kudüs & 20 & - & - \\
\hline 32. & İstoki v. Yani & Meis adası & 40 & Ticaret & - \\
\hline 33. & Yani v. İstokroz & Elmalı'ya gidip gelmiştir & 22 & - & - \\
\hline 34. & Yuriyi v. Yani & Hamid Sancağı & 28 & Ticaret & - \\
\hline 35. & Franço v. Kostandi & Dersaadet & 45 & Ticaret & - \\
\hline 36. & Yuriyi v. Franco & Firari & 21 & Firar & - \\
\hline 37. & Hralanboz v. Franco & Dersaadet & 14 & Ticaret & - \\
\hline 38. & Todoruz v. İstirati & İskenderiye & 37 & Ticaret & - \\
\hline 39. & Dimitri v. İstoki & İzmir & 30 & Ticaret & - \\
\hline 40. & Estadi v. İstirati & Hamid Sancağ & 45 & - & - \\
\hline
\end{tabular}

Kaynak: BOA., ML.VRD.CMH.d., 1127, 2-21.

Şurası kesindir ki diyar-1 ahara giden gayrimüslimler tabloda gösterilenlerle sınırlı değildi. Burada verilenler sadece sayım sırasında dışarıda bulunanlar ya da kısa bir süre önce gidip gelmiş olanlardı. Başka tarihlerde farklı kişiler de benzer ya da başka şehirlere gidip gelmekteydi. Bunlardan bazıları ise uzun süreli olarak diyar-1 ahara gitmişti. Diyar-1 aharda uzun süreli bulunanların kayıtları Antalya cizye defterlerinden düşürülmekteydi. Bunun için geçerli sürenin 9-10 yıllık bir süreç olduğu anlaşılmaktadır. 1850-1851 (1267) ve 1851-1852 (1268) yıllarında 1259 (1843) yılından itibaren diyar-1 aharda bulunan veya Antalya'dan göçüp gittikleri anlaşılan kişiler "terkin" edilmişlerdir. 1850-1851 (1267) yılında kayıtları Antalya cizyesinden düşürülen 21 kişi vardı. Bu durumda olanların büyük kısmı aslen Antalyalı olmayıp, eski memleketlerine dönenlerdi.

Tablo 7. 1850-1851 (1267) Yılında Antalya Cizyesinden Çıkarılanlar

\begin{tabular}{|c|c|c|}
\hline Adı & Nereye Gittiği & Ne Zaman Gittiği \\
\hline İstefan v. Kirye & Der-i Aliyye & 1259 \\
\hline David v. Nikola & An-asl Kıbrıslı olup vilayeti tarafina gitmiştir. & - \\
\hline $\begin{array}{l}\text { Nikola v. David (David } \\
\text { v. Nikola'nın oğlu) }\end{array}$ & An-asl Kıbrıslı olup vilayeti tarafina gitmiştir. & - \\
\hline Keryüz v. Kireyi & 1259 tarihinden beri Tersane-i Amireye gitmiştir & 1253 \\
\hline Anaştaş v. Ligori & $\begin{array}{l}\text { Aslen Menteşe Sancağında Kayı kazasından olup } \\
\text { orada mutavattın olmuştur }\end{array}$ & - \\
\hline Mihail v. Sava & 1263 tarihinden beri Tersane-i Amireye gitmiştir & - \\
\hline Anaştaş v. Vasili & Meis ceziresinde mutavattın olmuştur & - \\
\hline Vasili v. Konstandi & İskenderiye'de mutavattın olmuştur. & - \\
\hline İstirati v. Konstandi & Kudüs'te mutavattın olmuştur. & - \\
\hline
\end{tabular}




\begin{tabular}{|l|l|l|}
\hline Mihail v. Yuriyi & Kibrıslı olup vilayetine gitmiştir & \\
\hline Ligori v. Solomon & Girit ceziresine tavattun etmiştir & - \\
\hline Mihail v. Leya & Patnos ceziresinde tavattun etmiştir & - \\
\hline Atnaş v. Anton & Meis ceziresinde tavattun etmiştir & - \\
\hline Nikola v. Lefter & Alaiyeli olup vilayetine gitmiştir & - \\
\hline Nikola v. Yuriyi & Sakızlı olup firar etmiştir & - \\
\hline Yuriyi v. Yani & Isparta'ya tavattun etmiştir & - \\
\hline Yani v. Foti & 63 tarihinde Tersane-i Amireye gitmiştir & - \\
\hline Luka v. Baris & Ispartalı olup vilayetine gitmiştir & - \\
\hline Diimitri v. İstoki & İzmir'de tavattun etmiştir & - \\
\hline Panayot v. Kiryako & Burdurlu olup vilayetine nakl etmiştir & - \\
\hline
\end{tabular}

Kaynak: BOA., ML.VRD.CMH.d., 1251, 2-23

1851-1852 (1268) yılında ise 19 kişinin kaydı terkin edilmiştir. Terkinlerin 17'sinin gerekçelerinde haneleriyle Antalya'dan kalkarak başka şehirlere göçüp oralarda "mutavattın" olmak gösterilmiştir. Bunlardan bazıları memleketlerine geri dönmüşlerdi. Örneğin Makbûle mahallesinde yaşamakta olan Pandeli veled-i Yani adlı Rum aslen Alaiyeli olup hanesiyle birlikte tekrar Alaiye tarafina dönmüştü (BOA., ML.VRD.CMH.d., 1346, 11).

Antalyalı gayrimüslimlerden düzenli olarak diyar-1 aharda bulunanların varlığı çoğunlukla şehirler arası ticaret yapanlarla ilgiliydi. Bunun yanında bazılarının eski memleketlerine dönüş yapmaları Antalya'ya alışamadıklarını ve/veya eski memleketleriyle bağlantılarını koparmadıklarını göstermektedir.

\section{Yabancı Gayrimüslimler (Yabancıyan)}

Bir ticaret ve liman şehri olan Antalya her zaman şehir dışından misafirler ağırlamıştır. Bu bakımdan şehirde yerleşik gayrimüslim nüfus yanında devamlı surette misafir, ticaret, göç vb. gerekçelerle gelen "yabancıyân" olarak tanımlanan bir nüfus da bulunmaktaydı.

Cizye sayımları yapılırken vergi kaybını önlemek amacıyla yerli olup olmadığına bakılmaksızın sayım sırasında hazır bulunan tüm cizyegüzâr nüfus kayda geçirilirdi. Dolayısıyla cizye sayımları esnasında çeşitli sebeplerle Antalya'da bulunan gayrimüslimler de cizye evraklarını buradan alacakları için cizye defterlerine kaydedilmişlerdir. Bunların Antalya'ya geliş sebepleri yazılmamakla birlikte kişilerin geldikleri şehirler daha çok ticarî gerekçelere işaret etmektedir.

"Yabanciyân" gayrimüslimler 1843 tarihli cizye defterinde "Rumiyân" ve "Ermeniyân" olarak ayrı ayrı kaydedilmişken diğer yıllarda Rumlar, Ermeniler ve Yahudiler böyle bir ayrım olmaksızın "re 'âyâ" adı altında tek bir kayıtta toplanmışlardır. Bunların sayıları 1843 tarihinde 168 'dir. Bu sayının 148'i Rum, 20'si Ermeni'dir. Bu yıl Yahudi yabancı gösterilmemiştir. 1846 ile 1852 yılları arasında 260 ile 290 arasında değişen sayıda Rum, Ermeni ve Yahudi çeşitli gerekçelerle Antalya'da bulunmuştur.

1843 yılında 148 Rum'dan şehirleri kaydedilen 141'inin memleketleri şöyleydi: Isparta (43), Kıbris (38), Burdur (18), Alaiye (12), Filibe (4), Kay (3), Elmalı (2), Gümüşhane (2), İstanbul (2), Rodos (2), Kayseri (2), Rumeli (2), Sakız (2), Sile (2), Yafa (1), Zombaki (1), Çeşme (1), Fertek (1), İzmir (1), Konya (1), Akşehir (1) (BOA., ML.VRD.CMH.d., 171, 26-29).

Antalya'ya gelen Rumların memleketlerine bakıldığında daha çok yakın bölgeler olduğu görülür. En fazla Rum Isparta, Kıbrıs, Burdur ve Alaiye'den gelmişti. Bu 4 bölgeden gelen Rumlar toplam miktarın \% 79'una tekabül etmektedir.

Ermeniler ise, Harputlu (3), Elmalı1ı (2), Kayserili (2), Arapkirli (2), Afyonkarahisarlı (2), 
Divriğili (2), Adapazarlı (1), Acemli (İran) (1), Ankaralı (1), Erzurumlu (1), Âsitâneli (İstanbul) (1), İzmirli (1), Rodoslu (1) idi (BOA., ML.VRD.CMH.d., 171, 29).

1847 (1263) yılında yabancı mükelleflerin yaş ortalamaları 32 idi. 290 yabancı gayrimüslimin 78'i (\% 27) Kıbrıslı idi. Bunun yanında 38'i (\% 13,10) Ispartalı, 22'si (\% 7,6) Alaiyeli, 15'i $(\%$ 5,17) Rodoslu idi (BOA., ML.VRD.CMH.d., 733, 23-27).

Yabancı gayrimüslim içerisinde kadınlar ve çocuklar sayılmamışlarsa da bu yanlarında çocuk ve kadınların bulunmadığı anlamına gelmemektedir. Kayıtlı yabancı gayrimüslimlerin yaşlarına bakıldığında büyük çoğunluğunun ailecek geldikleri anlaşılmaktadır. 1848-49 (H. 1265) (BOA., ML.VRD.CMH.d., 1127, 17-21) sayımına göre 287 yabancı içerisinde 15-20 yaş aras1 nüfus $50(\%$ 17,5) kişiydi. Bu durum vergi mükellefi kabul edilemeyen daha küçük çocukların ve bunlar yanında ailelerin diğer fertlerinin de varlığını teyit etmektedir. Muhakkak ki yabancı nüfusun büyük çoğunluğu aileleriyle birlikte gelmişlerdi. Üstelik bu nüfusun önemli bir kısmı da kısa süreliğine gelmemişti. Bazıları Antalya'da uzun süreli ikamet etmekteydi. 1850-51 (H. 1267) ve 1851-52 (H.1268) yıllarında son birkaç yıldır daimi olarak Antalya'da ikamet üzere olan kişiler "mutavattın" (yerleşik/yerli) sayılmışlardır. 1850-51 (H. 1267) (BOA., ML.VRD.CMH.d., 1251, 25-26) yılında 89 kişi mutavattın hükmünü kazanmıştı. 1851-52 (H.1268) (BOA., ML.VRD.CMH.d., 1346, 15-16) y1lında aynı liste tekrarlanmakla beraber bunlara 2 kişi daha eklenerek 91 kişi mutavattın gösterilmiştir. Öte yandan bu iki y1l yabancı nüfus gösterilmemişti.

1850-51 (1267) yılında mutavattın hükmü kazanan 89 kişinin 46'sı (\% 51,7) Kıbrıs, 10 ’u (\% 11,24) Burdur, 7'si (\% 7,9) Keşan, 5'i Alaiye (\% 5,62), 4'ü Ankara (\% 4,5), 3’ü $(\%$ 3,37) Kayserili'dir. Buna göre mutavattın sayılan nüfusun yarıdan fazlası Kıbrıslıydı. Bu ise Yabancı gayrimüslimler içerisinde hatırı sayılır bir oranda Kıbrıslının bulunduğuna işaret ederken Antalya ile Kıbrıs arasında eskiden beri süregelen münasebetin de göstergesidir.

\section{Antalya Gayrimüslimlerinin Yaş Durumları}

Bir toplumun yaş oranlarının bilinmesi o toplumun süreklilik, çalışabilirlik, doğum, ölüm vb. bilgilerin ortaya çıkarılabilmesi açısından önemlidir. Cizye defterlerinde gayrimüslimlerin yaşları da kaydedildiğinden defterlerden bu yönde verilere ulaşılabilmektedir (1850-51 (1267) ve 1851-52 (1268) y1llarında yaşlar kaydedilmemiştir). Ancak incelenen defterler içerisinde vergi mükellefi olsun olmasın bütün nüfusun kayıtlı bulunduğu tek defter yukarıda belirtildiği üzere 1840 yılı nüfus sayımı esas alınarak yapılan 1843 tarihli cizye defterdir. Bu defterde de tamamı kaydedilmiş olanlar sadece yerleşik nüfustur. Şehre dışarıdan gelen gayrimüslimlerin vergiye tabi olmayanları kaydedilmemiştir. Bu yüzden sadece Antalyalı gayrimüslimlerin yaş oranları değerlendirilebildi. Ayrıca çeşitli nedenlerde kayıtlardan düşürülenler (vefat, reft, mükerrer vb.) değerlendirme dışı bırakıldı.

Yaş oranlarının kategorize edilmesinde şu hususlar göz önünde bulunduruldu: 0-3 aralığı bebek, 4-14 yaşları cizyeye tabi olmayan çocuk, 15-24 yaşları nüfus sayımlarında "şâb-i emred" olarak gösterilen genç, 25-45 yaşları çalışabilirlik ve verimlilik açılarından en uygun yaşlar, 4660 aralığı ömrün kısalığı düşünüldüğünde yaşl1lık ve çalışma veriminden düşüşün başladığı dönem, 61 yaş üzeri ise ihtiyar sayılmıştır. Ayrıca 7 kişinin de yaşları gösterilmemiştir. Dolayısıyla değerlendirmeye alınan kişi sayısı 1272'dir. 
Tablo 8. 1843 Yılı Cizye Sayımına Göre Antalya Rumlarının Yaş Oranları

\begin{tabular}{|c|c|c|c|c|c|c|c|c|c|c|c|c|c|c|c|c|c|}
\hline \multirow[b]{2}{*}{ Mahalleler } & \multicolumn{2}{|c|}{$0-3$} & \multicolumn{2}{|c|}{$4-13$} & \multicolumn{2}{|c|}{$14-18$} & \multicolumn{2}{|c|}{$19-24$} & \multicolumn{2}{|c|}{$25-45$} & \multicolumn{2}{|c|}{$46-60$} & \multicolumn{2}{|c|}{$61-70$} & \multicolumn{2}{|c|}{$71+$} & \multirow{2}{*}{ 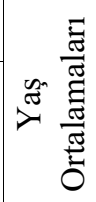 } \\
\hline & $\frac{\vec{t}}{i=}$ & $\%$ & 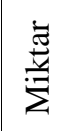 & $\%$ & 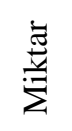 & $\%$ & 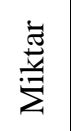 & of & 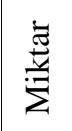 & $\%$ & 昙 & $\%$ & 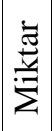 & $\%$ & 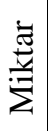 & $\%$ & \\
\hline edi & 48 & 9,49 & 134 & 2 & 55 & & J & & 1 & 3 & 41 & 8 & 7 & ,38 & 1 & ,2 & 22,9 \\
\hline $\tan$ & 37 & 9,41 & 113 & & 54 & 15,1 & 45 & & 114 & 25 & 27 & 6,87 & 2 & 0,51 & 1 & 0,25 & 21,3 \\
\hline Takb & 33 & 9,27 & 103 & 28,93 & 30 & 28,9 & 46 & 12,92 & 128 & 36 & 15 & 4,21 & 1 & 0,28 & 0 & 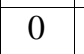 & 21 \\
\hline $\mathrm{rm}$ & 1 & 5,88 & 5 & 29,41 & 1 & 5,88 & 0 & 0 & 7 & 41,6 & 3 & 17,65 & 0 & 0 & 0 & 0 & 26,11 \\
\hline opla & 119 & 9,36 & 355 & 27,91 & 140 & 11,01 & 130 & 10,36 & 430 & 33,71 & 86 & 6,61 & 10 & 0,8 & 2 & 0,16 & 22 \\
\hline
\end{tabular}

Kaynak: BOA., ML.VRD.CMH.d., 171, 2-25.

*Cami-i Cedid mahallesinde 2 kişinin yaşı kaydedilmemişti.

Cizye defterlerine göre Antalya yerli gayrimüslimlerinin yaş oranlarına bakıldığında oldukça genç bir nüfus yapısına sahip oldukları görülür. 18 yaş ve altı nüfus toplam nüfusun neredeyse yarısına tekabül etmekteydi $(\% 48,28)$. Nüfusun en geniş yaş kitlesini çalışabilirlik ve verimlilik açısından en uygun yaşlar sayılan 25-45 aralığında bulunmaktadır (\%33,71). Toplam nüfusun $1 / 3$ 'ü bu yaş diliminde yer almaktadır. Görece olgun yaş bulunan 46-60 aralığ 1 ise nüfusun \% 6,61'ine tekabül etmekteydi. Bu yaş aralığındaki nüfusta yaşlılık sebebiyle vergiden muaf tutulan kişi sayısı sadece birdir (BOA., ML.VRD.CMH.d., 171, 3). Bu durum bu yaş aralığındaki kişilerin de çalışabilirlik bakımından uygun seviyelerde olduğunu göstermektedir. Yaşlı nüfus olarak nitelendirilebilecek 60 yaş ve üstü nüfus ise sadece 12 kişi olup toplam nüfus içerisindeki oranı yüzde biri bulmamaktadır. Bunlar içerisinde en yaşlı kişi Makbûle mahallesinden 93 yaşında bulunan Pandeli veled-i Gorker'dir (BOA., ML.VRD.CMH.d., 171, 11).

Az sayıda bulunan Ermenilerde 60 yaş üstü hiç kimse yoktu. Ermeni nüfus için şaşırtıc1 olanı 19-24 yaş aralığında kimsenin bulunmamasıydı. Bu sebeple Ermeni nüfusun yaş ortalaması Rum nüfusa göre nispeten bir miktar daha yüksekti $(26,11)$. Ancak bu bile genç bir nüfus demekti.

\section{Antalya Gayrimüslimlerinin Hastalık, Sakatlık ve Yaşlılık Durumları}

Tanzimat'ın en önemli özelliklerinden biri herkesin hal ve tahammülüne göre bir vergilendirme esasını yerleştirme çabasıydı. Vergi sayımlarında bu hususa oldukça dikkat edilmiştir. $\mathrm{Bu}$ kapsamda mükellefiyeti etkileyebilecek hastalık, sakatlık ve yaşlılık durumları kaydedilmiş, bu durumda bulunanlardan vergi alınamamıştır.

Gayrimüslimlerin fiziki engel durumlarında dikkat edilen husus çalışarak geçimini sağlayıp sağlamayacağı idi. Bu anlamda çalışmaya engel olan fiziki görüntülerden en çok karşılaşılanı amel-mande, yaşl1lık ve âmâ durumlarıydı. Yaşl11ık günümüzde bir engellilik öğesi olmasa da incelenen göreceli olarak çalışmayı önleyen bir durum arz edebildiğinden cizye sayımlarında bu manada kaydedilmiştir. 
Tablo 9. Cizye Defterlerine Göre Gayrimüslimlerin Fiziki Engellik Durumları

\begin{tabular}{|l|c|c|c|c|c|c|c|c|}
\hline \multicolumn{1}{|c|}{ Y11 } & $\begin{array}{c}\text { Ama/Gözleri } \\
\text { Alil }\end{array}$ & Mariz & $\begin{array}{c}\text { Alil/Bi- } \\
\text { Kudret }\end{array}$ & Kötürüm & Bi-sûretli & $\begin{array}{c}\text { h̀tiyar/ } \\
\text { Musin }\end{array}$ & Amelmande & Toplam \\
\hline $1843(1259)$ & 7 & & & & 2 & 7 & & 16 \\
\hline $1846(1262)$ & 7 & 1 & 2 & 1 & 1 & 2 & 4 & 18 \\
\hline $1847(1263)$ & 1 & & & & & 1 & 4 & 6 \\
\hline $1848(1264)$ & 1 & & & & & 6 & 4 & 11 \\
\hline $1848-49(1265)$ & & 3 & & & & & 8 & 11 \\
\hline $1250-51(1267)$ & 5 & & 1 & & & & 14 & 20 \\
\hline $1251-52(1268)$ & & & & & & & 2 & 2 \\
\hline
\end{tabular}

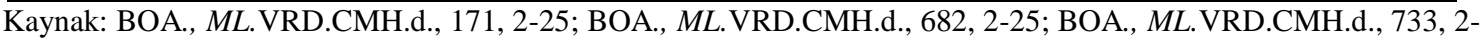
22; BOA., ML.VRD.CMH.d., 926, 2-18; BOA., ML.VRD.CMH.d., 1127, 2-17; BOA., ML.VRD.CMH.d., 1251, $2-$ 24; BOA., ML.VRD.CMH.d., 1346, 2-15.

Tablodan da izlenebildiği üzere çalışmaya engel teşkil edip en fazla kaydedilen durum amel-mande ve ihtiyarlık idi. Amel-mande tabiri genel olarak "iş göremeyen" anlamına gelmektedir. Bu yaşlılık, sakatlık vb. nedenlerle olabilirdi. Yaşl1lık ve fiziksel engeller dolaysıyla vergiden muafiyet durumu nüfusun oldukça az bir kısmını ilgilendiren bir vaziyetteydi. Bu bakımdan genel olarak gayrimüslim nüfusun çalışabilirlik yönünden olumsuz bir görüntüsünün bulunduğu söylenemez.

\section{Gayrimüslimlerin Cizye Mükellefiyetleri}

Tanzimat Fermanı'nın ortaya koyduğu en önemli ilkelerden biri herkesin hal ve tahammülüne göre vergilendirilmesi idi. Cizye kayıtlarının tutulmasında da bu prensibe bağlı kalındı. Cizye defterleri birincil olarak gayrimüslim nüfusun cizye mükellefiyetlerini tespit etmek ve kayıt altına almak amacıyla tutuldu. Dolayısıyla cizye vergi kayıtlarından kişilerin ekonomik durumlarının tespit edilebilmesi mümkün olabilmektedir.

Cizye mükellefleri genellikle 14 yaştan itibaren kaydedilmişlerdir. Ancak 13 yaşında mükellefler de istisnai olarak kayıtlıdır (BOA., ML.VRD.CMH.d., 682, 6). Anlaşıldığı kadarıyla çocukların boy ve fiziki durumlarına bakılarak da mükellef sayılabilmekteydiler.

Cizye defterleri esas itibariyle cizye mükellefiyetlerini, cizye evrak türlerini, gerekçeleriyle birlikte vergiden muaf olanları kaydetmektedir. Bu yönden cizye defterlerinden gayrimüslimlerin cizye vergi mükellefiyetleri rahatlıkla öğrenilebilmektedir. Cizye, bireysel olarak kişilerin ekonomik durumlarına göre ednâ, evsat ve âlâ (esnaf-1 selâse) olmak üzere üç grupta tahsil edilmekteydi. Ekonomik olarak gelir durumu ve varlıklarına göre üst düzeyde bulunanlar âlâ, orta düzeyde bulunanlar evsat ve daha düşük gelire sahip olanlar ise ednâ türünden cizye ödemekteydiler. 19. yüzyıl ortalarında, II. Mahmut döneminde (1834) belirlenen esnaf-1 selâse miktarları geçerliydi: Buna göre âlâ 60, evsat 30 ve ednâ 15 kuruş idi (Nedkoff 1944, 627).

Burada önemli olan husus kimin hangi durumda, hangi meslek, hangi varlık ya da hangi gelir durumuna göre hangi vergi türüne dâhil edildiğidir. Ne yazık ki cizye defterleri böylesi bir bilgiyi vermekten oldukça uzaktır. Çok daha kompakt sonuçlara ulaşılabilmek için cizye defterleriyle birlikte daha farklı kayıt türlerine müracaat etmek gerekmektedir. Ancak yine de cizye defterlerinde âlâ sınıf cizye evrakı mükelleflerine bakıldığında büyük çoğunluğunun bir mesleğe sahip oldukları gözlemlenirken, edna sınıfında ise meslek sahibi olma oranının düşüklüğü göze çarpmaktadır. Sözgelimi 1846 yılında Cami-i Cedid mahallesinde 16 âlâ mükellefinin sadece 1 'inin meslekleri kaydedilmemişti. Yaş itibariyle de biri (mesleği yazılmayan-29 yaş) hariç 35 yaşıı üzerinde olup yaş ortalamaları 45 idi. Aynı mahallede 158 edna türü evrak sahibinin sadece 63'ünün meslekleri kaydedilmişti. Ayrıca edna türü mükelleflerinin yaş ortalaması 32 idi. 
Özellikle yaş itibariyle yeni mükellef olmuş gençlerin büyük kısmı edna türüne kayıtlı idiler (BOA., ML.VRD.CMH.d., 682, 2-10).

Antalya gayrimüslimlerinin cizye vergilerinin tahsilinde belirtilmesi gereken hususlardan biri de Antalya'da bulunan Kazgancıyan Kıptiyan'ın Müslüman olmalarına rağmen cizyeye tabi kılınmalarıdır. Bu bakımdan yerli gayrimüslimlerin diğer hususlarında Kazgancıyan Kıptiyan Müslüman olmalarından dolayı değerlendirmelere alınmamışsa da cizye mükellefi sayıldıkları için vergilendirme konusuna dâhil edilmişlerdir.

Osmanlı Devleti'nde Kıptilerin Müslüman olanlarından da cizye vergisi alınmasının nedeni kendilerinin çok farklı bir yönteme tâbi tutulmalarıdır. Kıptiler Müslüman ve gayrimüslim olarak ikiye ayrılmalarına rağmen hukukî olarak bir sayılmışlardır. Çünkü Kıptiler Osmanlı Devleti'nde hiçbir zaman millet (community) olma vasfını kazanamamışlar ve bu bakımdan diğer milletlerden faklı bir uygulamaya tâbi tutulmuşlardır. Kıptilerin yerleşik olmayıp gezici durumda bulunmaları nedeniyle kendilerinden düzenli vergi toplanamaması ve askere alınamamaları cizye mükellefi olmalarının nedeni olarak gösterilmektedir (Altınöz 2013, 236).

Tanzimat döneminin ilk yıllarına rastlayan cizye sayım defterlerinde Antalya'daki cizye mükellefiyetleri şöyleydi:

Tablo 10. Antalya Gayrimüslimleri (Yerli ve Yabancıyan) ve Kazgancıyan Kıptiyân'ın (İslâm) Cizye Mükellefiyetleri (1843-1852)

\begin{tabular}{|l|c|c|c|c|c|}
\hline \multicolumn{1}{|c|}{ Yıl } & Âlâ (\%) & Evsat (\%) & Ednâ (\%) & $\begin{array}{c}\text { Toplam Cizye } \\
\text { Mükellefi (\%) }\end{array}$ & $\begin{array}{c}\text { Toplanan Cizye } \\
\text { Miktarı (Kuruş) }\end{array}$ \\
\hline $1843(1259)$ & $58(6,81)$ & $416(48,83)$ & $378(44,36)$ & $852(100)$ & 21.630 \\
\hline 1846 (H. 1262) & $55(6,78)$ & $385(47,41)$ & $372(45,81)$ & $812(100)$ & 20.430 \\
\hline $1847(1263)$ & $51(6,17)$ & $379(45,83)$ & $397(48,00)$ & $827(100)$ & 20.385 \\
\hline 1848 (H. 1264) & $56(6,02)$ & $363(38,99)$ & $512(54,99)$ & $931(100)$ & 21.930 \\
\hline $1848-49$ (H. 1265) & $54(6,58)$ & $352(42,93)$ & $414(50,49)$ & $820(100)$ & 20.010 \\
\hline $1850-51$ (H. 1267) & $54(6,14)$ & $354(40,27)$ & $471(53,59)$ & $879(100)$ & 20.925 \\
\hline $1851-52$ (H.1268) & $54(6,10)$ & $361(40,79)$ & $470(53,11)$ & $885(100)$ & 21.120 \\
\hline
\end{tabular}

Kaynak: BOA., ML.VRD.CMH.d., 171, 2-29; BOA., ML.VRD.CMH.d., 682, 2-30; BOA., ML.VRD.CMH.d., 733, 2-27; BOA., ML.VRD.CMH.d., 926, 2-22; BOA., ML.VRD.CMH.d., 1127, 2-21; BOA., ML.VRD.CMH.d., 1251, 2 26; BOA., ML.VRD.CMH.d., 1346, 2-16.

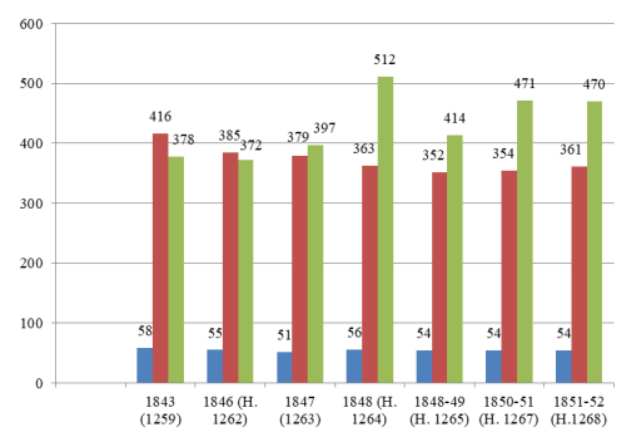

Grafik 2. Cizye Türlerinin Yıllar İçerisinde Dağılımı

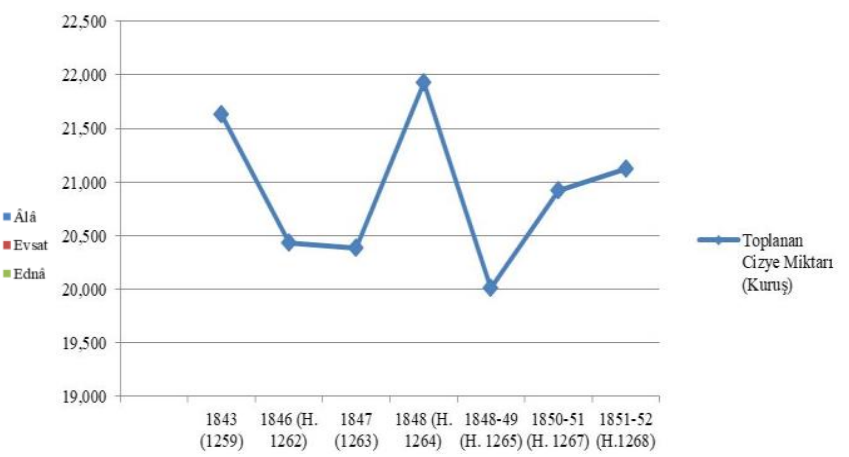

Grafik 3. Toplanan Cizye Miktarı

En yüksek cizye tutarı 21.930 kuruş ile 1848 (1264) yılında gerçekleşmiştir. Cizye gelirinin en düşük olduğu yıl ise 20.010 kuruş ile 1848-1849 (1265) yılıdır. Yıllara göre bakıldığında 
toplanan cizye miktarında bir dalgalanma bulunduğu izlenmektedir. Bu dalgalanmanın nedeni aşağıdaki grafiklerde net bir şekilde görüleceği üzere nüfus azalması değildir. Bu dalgalanmanın nedeni tablo ve grafiklerde de izlenebileceği şekilde cizye evrakı türlerinde görülen dalgalanmadır.

Antalya gayrimüslimlerinin cizye mükellefiyetlerinde âlâ sınıfı cizye mükellefi azdır. Her sayımda ekonomik durumları üst düzeyde bulunan kişiler yaklaşık \% 6 seviyelerindedir. Âlâ türü cizye hiçbir zaman \% 7'yi bulmamıştır. Evsat ve ednâ sınıflarından cizye türleri ise y1ldan yıla büyük farkl1lıklar göstermişlerdir. Evsat türü cizye genel olarak bir düşüş sergilerken edna türü cizye yükseliş göstermiştir. Âlâ, evsat ve ednâ türlerinden alınan cizye vergilerine bakıldığında Antalya gayrimüslimlerinin ekonomik açıdan genel itiba-

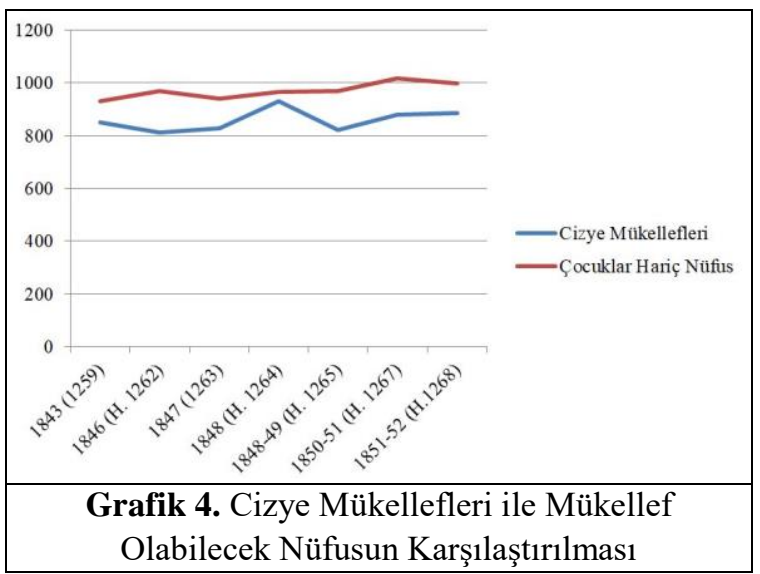
riyle orta ve alt gelir guruplarında bulunduklarını söylemek mümkündür. 1843 (\% 48,82) ve 1846 yıllarında (\% 47,41) evsat türü en fazla orana sahipken ednâ türü ilerleyen yıllarda \% 55 seviyelerine yaklaşmıştır.

Edna türü cizyedeki bu artışın en önemli nedeni yabancı nüfus içerisindeki edna türünün fazlalığıdır. Edna türü cizyenin en yüksek olduğu yıl (1848) yabanciyan içerisinde 278 mükellef içerisinde 207 (\% 74,5) kişi edna türüne kaydedilmişti. 1850-51 (H. 1267) ve 1851-52 (H.1268) yıllarında da yabancı nüfus olmamakla birlikte mutavattın sayılan nüfusun neredeyse tamamı edna türü cizye mükellefiydi. Bu iki yıl âlâ mükellefi yok iken toplam 180 mükellef içerisinde edna sayısı 178 (\% 89) idi. Bu ise genel toplamda edna türü cizye sayısını artırmıştır.

Vergi kayıtlarında Müslüman olmalarına karşın mükellef sayılan Kıptiyan'ın bulunduğu belirtilmişti. Bunların sayıları yüksek rakamlara ulaşmamaktadır. Hatta 1846 sayımında hiçbir Kıpti kaydedilememişti. Diğer yıllarda da nüfus ve mükellef sayıları büyük dalgalanma göstermiştir. Bu dalgalanmanın nedeni Kıpti nüfusun gezer olması nedeniyle bir yıl Antalya'da iken öbür yıl Aydın ya da Menteşe sancağına gidebilmesiydi.

Tablo 11. Antalya Kıptilerinin (İslam) Cizye Vergileri (1843-1852)

\begin{tabular}{|l|c|c|c|c|c|c|}
\hline \multirow{2}{*}{ Y11 } & \multicolumn{4}{|c|}{ Cizye Evrak1 Türüne Göre Hane Say1s1 } & \multirow{2}{*}{$\begin{array}{c}\text { Toplam } \\
\text { Mükellef Sayıs1 }\end{array}$} & \multirow{2}{*}{ Toplam Nüfus } \\
\cline { 2 - 5 } & Ednâ & Evsat & Âlâ & Muaf & 28 & 59 \\
\hline $1843(1259)$ & 10 & 18 & 0 & 0 & - & - \\
\hline $1846(1262)$ & - & - & - & - & 4 & 18 \\
\hline $1847(1263)$ & 3 & 1 & 0 & 0 & 6 & 15 \\
\hline $1848(1264)$ & 3 & 3 & 0 & 1 & 8 & 18 \\
\hline $1848-49(1265)$ & 3 & 5 & 0 & 0 & - & - \\
\hline $1849-50(1266)$ & - & - & - & - & 9 & 16 \\
\hline $1850-51(1267)$ & 4 & 5 & 0 & 0 & 17 & 18 \\
\hline $1851-52(1268)$ & 11 & 6 & 0 & 0 & & 28 \\
\hline
\end{tabular}

Kaynak (sirasiyla): BOA., ML.VRD.CMH.d., 171, 24-25; BOA., ML.VRD.CMH.d., 682, 25; BOA.,

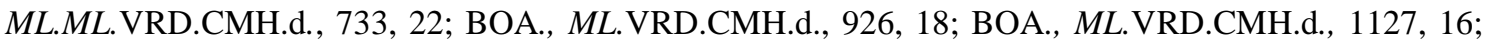
BOA., KK.d., 3899, 23; BOA., ML.VRD.CMH.d., 1251, 23; BOA., ML.VRD.CMH.d., 1346, 15. 
Münhasıran Antalya Ermenilerinin ekonomik durumlarına bakıldığında sayıca büyük bir değişiklik olmadığı görülür. Antalya Ermenilerinde cizye mükellefi sayısı 7-9 arasında değişmiştir. Âlâ türü cizye mükellefi Ermeni yoktu.

Tablo 12. Antalya Ermenilerinin Cizye Vergileri (1843-1852)

\begin{tabular}{|c|c|c|c|c|c|c|}
\hline \multirow[b]{2}{*}{ Y1l } & \multicolumn{4}{|c|}{ Cizye Evrakı Türüne Göre Hane Sayısı } & \multirow[b]{2}{*}{$\begin{array}{l}\text { Toplam } \\
\text { Mükellef } \\
\text { Sayısı }\end{array}$} & \multirow[b]{2}{*}{$\begin{array}{l}\text { Toplam } \\
\text { Nüfus }\end{array}$} \\
\hline & Ednâ & Evsat & Âlâ & Muaf & & \\
\hline $1843(1259)$ & 1 & 6 & 0 & 0 & 7 & 17 \\
\hline $1846(1262)$ & 4 & 5 & 0 & 2 & 9 & 11 \\
\hline $1847(1263)$ & 4 & 3 & 0 & 3 & 7 & 10 \\
\hline $1848(1264)$ & 6 & 3 & 0 & 2 & 9 & 11 \\
\hline $1848-49(1265)$ & 5 & 3 & 0 & 1 & 8 & 9 \\
\hline $1849-50(1266)$ & 5 & 3 & 0 & 0 & 8 & 8 \\
\hline $1850-51(1267)$ & 5 & 3 & 0 & 1 & 8 & 9 \\
\hline $1851-52(1268)$ & 5 & 3 & 0 & 0 & 8 & 8 \\
\hline
\end{tabular}

Kaynak (sırasıyla): BOA., ML.VRD.CMH.d., 171, 24-25; BOA., ML.VRD.CMH.d., 682, 25; BOA., ML.ML.VRD.CMH.d., 733, 22; BOA., ML.VRD.CMH.d., 926, 18; BOA., ML.VRD.CMH.d., 1127, 16; BOA., KK.d., 3899, 23; BOA., ML.VRD.CMH.d., 1251, 23; BOA., ML.VRD.CMH.d., 1346, 15.

Cizye defterlerinde sayım sırasında Antalya'da bulunan gayrimüslimler ve Kıptiler de cizye evraklarını buradan alacaklarından kaydedilmişlerdir. Muaf olanlar var ise bunlar kaydedilmemişlerdir. Buna göre yıllar itibariyle yabancıyanın cizye mükellefiyetleri şöyleydi:

Tablo 13. Antalya'da Yabanciyanın Ödediği Cizye

\begin{tabular}{|l|c|c|c|c|}
\hline Y1l & Ednâ & Evsat & Âlâ & Toplam \\
\hline $1843(1259)$ & 91 & 74 & 3 & 168 \\
\hline $1846(1262)$ & 187 & 67 & 6 & 260 \\
\hline $1847(1263)$ & 222 & 77 & 5 & 304 \\
\hline $1848(1264)$ & 211 & 67 & 6 & 284 \\
\hline $1848-49(1265)$ & 231 & 53 & 3 & 287 \\
\hline $1849-50(1266)$ & 227 & 52 & 2 & 281 \\
\hline $\begin{array}{l}1850-51(1267) \\
\text { (Mutavattın sayılanlar) }\end{array}$ & 77 & 12 & 0 & 89 \\
\hline $\begin{array}{l}\text { 1851-52 (1268) } \\
\text { (Mutavattın sayilanlar) }\end{array}$ & 81 & 10 & 0 & 91 \\
\hline
\end{tabular}

Yabancı cizye mükellefleri Antalya'da hatırı sayılır oranda idi. 1843 yılında 168 mükellef varken 1847 yılı itibariyle bu rakam 304'e kadar çıkmıştı. Ancak defterlerde 1850-51 (1267) ve 1851-52 (1268) yıllarında yabancı mükellefler kaydedilmemiştir. Bunun yerine son birkaç yıldır Antalya'da ikamet etmekte olanlar "mutavattın" hükmüne geçirilerek kaydedilmişlerdir. Bunların sayıları önceki yıllarda kaydedilen yabancı mükellef sayısından oldukça azdır. Bu ise bu iki yıl yabancıyan mükelleflerin kaydedilmediğini göstermektedir.

\section{Gayrimüslimlerin Meslekleri}

Cizye defterleri kişilerin gelir, meslek ve varlıklarına göre vergilendirmeyi esas aldığından kişilerin meslekleri de kaydedilebilmekteydi Bu bakımdan Antalyalı gayrimüslimlerin geçimle- 
rini sağladığı mesleklere cizye defterlerinden de ulaşabilmek mümkündür.

Antalya ilk kurulduğu dönemlerden beri bir ticaret şehri olagelmiştir. Bu özelliği Selçuklu döneminde belirgin hale gelmişse de Osmanlı döneminde de sürmüştür. Osmanlı Devleti'nin genel ekonomik gidişatı ve Doğu Akdeniz'de görülen ekonomik daralma ve dalgalanmalar nedeniyle Antalya ekonomisi 19. yüzyıl ortalarına geldiğinde eski canlılı̆̆ında değildi. Ancak bir liman şehri olarak Antalya'da ticari hareketliliğin tamamen kaybolduğu söylenemez. Cizye defterlerinde gayrimüslimlerin meslekleri de bu veriyi doğrulamaktadır.

19. yüzyıl ortalarında Antalya'da ekonomik faaliyetler daha çok tarım, hayvancılık, ticaret, zanaat üzerinden işlemekteydi. Tarım ve hayvancılık daha çok Müslümanların meslekleri iken ticaret ve zanaat ise gayrimüslimlerin meslekleri şeklindeydi. Bu sebeple gayrimüslimlerin ekonomik açıdan daha refah bulundukları bilinmektedir (Dinç 2005a, 127).

Antalya cizye defterlerinde bütün gayrimüslimlerin meslek bilgileri kaydedilmiş değildir. Tespit edilen defterlerden hiçbirinde gayrimüslimlerin meslekî bilgileri tam olarak verilmemiştir. Meslek bilgisi yazılan gayrimüslim sayısı düşük seviyelerdedir. 1843 (1259) tarihli cizye defterine göre Antalyalı gayrimüslimlerin kaydedilen meslekleri şöyleydi (BOA., ML.VRD. CMH.d., 171):

Berber (21), hademe (19), dülger (8), tüccar (8), Avrupa tüccarı (7), değirmenci (7), bahçıvan (6), semerci (3), attar (3), aşçı (2), bazergan (4), çilingir (3), kayıkçı (3), papaz (3), kalaycı (3), bezzaz (2), boyacı (1), çerçi (2), hekim (2), kuyumcu (2), kiremitçi (2), hancı (1), 1rgat (1), kahveci (1), yapıc1 (1), kebapçı (1), kürkçü (1), mısırc1 (2), pabuççu (1), yemenici (1), balıkçı (1), yolcu (1).

Berber sayısının gayrimüslimler arasında çokça yer alması gayrimüslim erkeklerin saç, sakal ve bıyık bakımlarına dikkat ettiklerinin bir göstergesi sayılmalıdır. Hademe olarak kaydedilen kişilerin bazıları Avrupa tüccarlarının yanında görevliydiler. Bir kısmı da ev hizmetinde görevli idi. Cizye defterlerinde kayıtlı tüccar sayısı Antalya gayrimüslimlerinde beklentilerin oldukça altındadır.

Antalyalı gayrimüslimlerin geçim kaynakları şüphesiz bu mesleklerden çok daha çeşitli ve fazlaydı. Fakat cizye sayımları sirasında tutulan kayıtlar ancak bu kadar bilgiye yer vermektedir. Bu sebeple bu yönde daha ayrıntılı bir değerlendirme yapma imkânı bulunmamaktadır. Bunun için nüfus ve temettuat defterleri gibi daha ayrıntılı bilgilerin bulunabileceği kaynaklara müracaat edilmesi gerekmektedir.

Antalyalı gayrimüslimlerden şehirlerarası ticaret yapanlar da vardı. 1848-49 (1265) yılında 25 (\% 2,5) gayrimüslim ticaret amaciyla İstanbul, İskenderiye, Kıbrıs, Elmalı vb. şehirlere gitmişti. Bu rakam yüksek miktarlara ulaşmasa da Antalyalı gayrimüslimlerin ekonomik alg1larının şehir ekonomisiyle kısıtlı olmadığını ve kapalı bir yapıda bulunmadıklarını göstermesi açısından önemlidir.

Yabancı mükellefler içerisinde de meslekler kaydedilmiştir. 1847 y1lında yabancıyan içerisinde mesleklere bakıldığında 304 kişinin (Kıptiler dâhil) 189'unun meslekleri kaydedilmişti. Bu rakamın 16'sı bâzergan, 12'si terzi, 11'i amele, 11'i hizmetkâr, 10'u dülger, 9 bahçıvan ve 9 duvarcı idi. Bunlar yanında abacı, aş̧̧ı, bakırcı, bakkal, berber, bohçacı, çerçi, çalgıcı, çeşmeci, çerçi, çıkıkçı, çubukçu, çulha, fesçi, ipekçi, katırcı, kuyumcu, kürkçü, pabuççu, pastırmac1, sazende, sülükçü, şekerci, taşçı, yolcu, yorgancı gibi meslekler de vardı. Meslekleri kayıtlı olanların Antalya'ya bu meslekleri yapmak üzere geldikleri varsayılmalıdır. Mesleği kaydedilmeyenler ise yaşça küçük veya olasılıkla misafirlik vb. nedenlerle gelenlerdi. 


\section{Gayrimüslimlerin Kullandıkları Adlar}

Cizye defterlerinde şahıs adları baba adlarıyla birlikte kaydedilmekteydi. Lakaplar konusunda ise cizye defterleri oldukça kısırdır. Çok nadir olarak aile adları ve lakaplar kaydedilmiştir. $\mathrm{Bu}$ nedenle bu kısımda cizye defterlerinde Antalya gayrimüslimlerinin kullandıkları adlar konu edilebilmektedir. Cizye defterleri sadece erkek nüfusu kaydettiğinden kadın adlarının bu defterlerden tespit edilebilmesi mümkün değildir. Çocuklar dâhil bütün nüfusun kayıtlı olduğu 1843 tarihli cizye defterlerinde yaygın olarak bulunan isimler şunlardır:

Yani 132, Yorgi 96, Nikola 77, Vasili 73, Kostanti 72, Pandelli 62, İstirati 58, Dimitri 54, Anastas 44, Mihail 42, Ligori 35, Kireyi 33, Todorus 32, Aton, 30, Yordan 26, Sava 24, Hralanbos 22, Kiryako 20, İstefan 18, Atnaş 14, Simon 13, Luka 13, Baris 12, Leyas 12, İstavri 10, Esir 10, Anaştaş 8, Yuriyi 8.

Görüldüğü üzere Yani adı en fazla tercih edilen isimdir. Kullanılan adlar genel olarak geleneksel Rum adlarıdır. Zira Antalya gayrimüslimlerinin neredeyse tamamına yakını Rumlardan oluşmaktaydı. Rumlar yanında bulunan az sayıdaki Ermenilerin kullandıkları adlar ise şöyleydi:

Mesrub, Artin, Migırdıç, Bedros, Esir, Agob, Haçik, Mergeren, Ovannes, Todorus, Vartan, Ağya (2), Sergiz, Manuk (2), Astor. Ermeni adlarında da geleneksel isimlere uyulduğu görülmektedir.

\section{Sonuç}

Cizye defterleri Osmanlı döneminde gayrimüslimlere münhasır tutulmuş ender kayıtlardan biridir. Bu defterler serisi Tanzimat döneminde vergi adaletini ve düzenliliğini sağlamak amacryla daha sıklıkla tutulmuştur. BOA'da Antalya'ya ait sekiz adet cizye defteri tespit edilmiştir. Bu defterlerden Antalya'da yerli ve yabancı gayrimüslim tebaanın yaşamakta olduğu görülmüştür. Yerli gayrimüslimler Rumlar ve Ermenilerden müteşekkil iken, yabancı olarak da Rum, Ermeni ve Museviler vard.

Antalya yerli gayrimüslimlerinin yaşadıkları mahalleler kale içerisinde bulunan Cami-i Cedid, Makbule ve Baba Doğan mahalleleriydi. Yerli Rumlar bu üç mahallede dağılmışken Ermeniler Baba Doğan mahallesinin sadece bir köşesinde toplanmışlardı. Yabancı gayrimüslimlerin ise nerede ikamet ettikleri cizye defterlerinde kayıt altına alınmamıştır.

Cizye defterlerine göre Antalya'da gayrimüslim erkek nüfus 1400, kadınların da dâhil edileceği hesaplamalara göre 2800'ün üzerinde bir rakama ulaşmıştı. Defterler yüzyılın ikinci yarısına doğru gayrimüslim nüfusta, özellikle Rumlar, bir nüfus artışına işaret etmektedir. $\mathrm{Bu}$ nüfustan bazıları her yıl çeşitli amaçlarla başka şehirlere gitmekteydi. Uzun süre şehirden ayrı kalanlar defterden düşürülmüşlerdir. Bunun yanında şehirde düzenli olarak çoğu ticaret amacıyla gelen bir yabancı gayrimüslim nüfus da vardı. Bunlardan da uzun süre şehirde ikamet edenler "mutavattın" hükmüne geçirilmişlerdir.

Cizye defterleri Antalya yerli gayrimüslimlerinin oldukça genç ve dinamik bir nüfus yapısına sahip olduğunu göstermektedir. Rum nüfusun yaş ortalaması 20'li yaşların başlarında (21-22), az sayıdaki Ermeni nüfusun ortalaması ise 26 dolaylarında idi. Ayrı bu nüfus içerisinde herhangi bir sakatlık dolayısıyla çalışamayacak durumda bulunanların sayısı da hiçbir yıl 20'yi geçmemektedir. $\mathrm{Bu}$ ise Antalya gayrimüslimlerinin çalışabilirlik açısından verimli olduğunu ortaya koymaktadır. Keza cizye ödemeleri bunu teyit etmektedir. Ancak bu Antalyalı gayrimüslimlerin varlıklı oldukları anlamına gelmemektedir. Cizye türlerine bakıldığında âlâ türü cizye miktarı hiçbir yıl \% 7'yi bulamamıştır. Evsat türü cizye 1843 ve 1846 sayımlarında en yüksek tür iken bu tarihten sonra ednâ türü cizye en yüksek seviyeye ulaşmıştır. 
Cizye defterlerinde kaydedilen meslekler yerli ve yabancı gayrimüslimlerinin tarım ve hayvancılıktan ziyade esnaf ve zanaat ile meşgul olduklarını ortaya koymaktadır. Bu ise gayrimüslimlerin (Rumlar ve Ermeniler) Osmanlı ekonomisindeki konumları ile uyumludur. Benzer şekilde Rumlar ve Ermenilerin kullandıkları isimler de Osmanlı toplumundaki geleneksel Rum ve Ermeni isimleri ile benzeşmektedir.

Sonuç olarak, elbette ki cizye defterleri tek başına bütün bir toplumsal yapıyı aydınlatmaya yetecek verileri sunmamaktadır. Antalya gayrimüslimlerinin idari, sosyal ve ekonomik hayat1 hakkında daha geniş bilgiler alabilmek için farklı belge koleksiyonlarına da müracaat edilmesi gerekmektedir. Ancak bu sayede çok daha kompakt sonuçlara ulaşılabilecektir.

\section{Mali Destek Bildirimi}

Bu çalışma Akdeniz Üniversitesi Bilimsel Araştırma Projeleri Koordinasyon Birimi tarafından desteklenen "Antalya'da Toplumsal Değişim ve Dönüşüm (1800-1923)" başlıklı ve 2014.01.0116.001 numaralı proje kapsamında üretilmiştir. 


\section{KAYNAKÇA}

Altınöz İ. (2013). Osmanlı Toplumunda Çingeneler. Ankara 2013.

Beden A. (2004). 1854-1859 Tarihleri Arasinda Antalya (8 No'lu Antalya Şer'iyye Sicilleri Defterine Göre). Yayımlanmamış Yüksek Lisans Tezi. Akdeniz Üniversitesi, Antalya 2004.

Bozkurt G. (1989). Gayrimüslim Osmanlı Vatandaşlarının Hukukî Durumu (1839-1914). Ankara 1989.

Sami B. S. (2012). Isparta Tarihi. Isparta 2012.

Braude B. (1982). "Foundation Myths of the Millet System". Ed. B. Braude \& B. Lewis, Christians and Jews in the Ottoman Empire I (1982) 69-88.

Çağatay N. (1947). "Osmanlı İmparatorluğunda Reayadan Alınan Vergi ve Resimler". Ankara Üniversitesi Dil ve Tarih-Coğrafya Fakültesi Dergisi V/5 (1947) 483-511.

Dinç G. (2005a). "Şer’iyye Sicillerine Göre XIX. Yüzyıl Ortalarında Antalya'da Ailenin Sosyo-Ekonomik Durumu". OTAM 17 (2005) 103-129.

Dinç G. (2005b). 9 No'lu Antalya Şer 'iyye Sicili Defterine Göre 1853-1859 Yılları Arasında Antalya Şehrinin İdarî ve Sosyo-Ekonomik Durumu. Yayımlanmamış Yüksek Lisans Tezi. Akdeniz Üniversitesi, Antalya 2005.

Durgun H. (2014). XIX. Yüzyılda Teke Sancă̆ı'na Bağlı Elmalı Kazası'nın Sosyo-Ekonomik Yapısı (18391914). Yayımlanmamış Doktora Tezi. Akdeniz Üniversitesi, Antalya 2014.

Durukan A. (1988). "Alâeddin Keykubad Döneminde Antalya". Antalya 2. Selçuklu Semineri (1988) 26-51.

Dündar R. (2012). “H. 1269 (1852-1853) Tarihli Kıbris Cizye Muhasebe Defteri”. ZfWT 4/2 (2012) 99-122.

Düstûr, Tertib 1, Cilt 1.

Ebu Abdullah Muhammed İbn-İ Battuta Tanci. (2004). İbn Batûta Seyahatnâmesi. İstanbul 2004.

Eken G. \& Şen H. (2016a). "Tanzimat Dönemi Cizye Defterlerine Göre Tokat’ta Gayrimüslimler”. Selçuk Üniversitesi Sosyal Bilimler Enstitüsü Dergisi 36 (2016) 161-175.

Eken G. \& Şen H. (2016b). "Tanzimat Dönemi Cizye Defterlerine Göre Amasya'da Gayrimüslimler”. Gaziosmanpaşa Üniversitesi Sosyal Bilimler Araştırmaları Dergisi 11/1 (2016) 105-132.

Ercan Y. (1999). “Osmanlı Devleti'nde Müslüman Olmayan Topluluklar”. Osmanlı IV (1999) 197-207.

Ercan Y. (1991). "Osmanlı İmparatorluğu'nda Gayrimüslimlerin Ödedikleri Vergiler ve Bu Vergilerin Doğurduğu Sosyal Sonuçlar”. Belleten LV/213 (1991) 371-381.

Erkal M. (1993). "Cizye”. TDV. İslâm Ansiklopedisi 8 (1993) 42-45.

Erpolat M. S. (2003). "Cizye Defterlerinin Sosyal ve İktisadî Tarih Araştırmaları Açısından Önemi: Diyarbakır Örneğì'. Sosyal Bilimler Araşttrma Dergisi 4 (2003) 189-204.

Gölen Z. (2003). “1267 (1851) Cizye Nizâm-nâmesi”. Belgeler XXIV/28 (2003) 41-51.

Gökbilgin M.T. (1988). “Çingeneler". İslâm Ansiklopedisi. Cilt III (1988) 420-426.

Gülsoy U. (2002), "Cizyeden Vatandaşlığa Osmanlı Gayrimüslimlerinin Askerlik Serüveni”. Türkler 14 (2002) 82-93.

İnalcık H. (1960). "Djizya”. The Encyclopaedia of Islam 2 (1960) 562-566.

İnalcık H. (1993.) "Osmanlılarda Cizye". İslâm Ansiklopedisi VIII (1993) 45-48.

Karal E. Z. (1943). Osmanlı Imparatorluğu'nda İlk Nüfus Sayımı, 1831. Ankara 1943.

Kocaoğlu B. (2017). Osmanlı Devleti'nde Cizye Vergisi ve Tanzimat Dönemi Uygulamalarından Bir Kesit: Kastamonu Örneği. Yayımlanmamış Yüksek Lisans Tezi. Kırıkkale Üniversitesi, Kırıkkale 2017.

Loklar B. (2012). Tanzimat Dönemi'nde Biga Sancă̆ı’nda Cizye Rejimi. Yayımlanmamış Yüksek Lisans Tezi. Çanakkale Onsekiz Mart Üniversitesi, Çanakkale 2012.

Nedkoff B. C. (1944). "Osmanlı İmparatorluğunda Cizye (Baş Vergisi) (Poll-Tax in the Ottoman Empire)". Belleten VIII/32 (1944) 599-652.

Özcoşar İ. \& Güneş H. H. (2006). "Osmanlı Devleti’nde Cizye ve 19. Yüzyıla Ait Bir Cizye Defteri: Cizre Sancağı'nın Cizye Defteri (Cizye Defter Numarası:375)”. Elektronik Sosyal Bilimler Dergisi 5/15 (2006) $159-179$.

Özel O. (2000). “Avarız ve Cizye Defterleri”. Osmanlı Devleti’nde Bilgi ve İstatistik (2000) 35-50. Ankara. 
ÖZTÜRK T. (2008). “XIII. Yüzyıl İlk Yarısı Trabzon Sancağı Nüfus Tespitinde Avarız ve Cizye Defterlerinin Kullanılabilirliği”. Uluslararası Karadeniz Incelemeleri Dergisi 5 (2008) 93-112.

Şen H. (2014). 1492 Numaralı Sivas Cizye Defterinin Değerlendirilmesi. Yayımlanmamış Yüksek Lisans Tezi. Cumhuriyet Üniversitesi, Sivas 2014.

Şen H. \& Eken G. (2016). "Tanzimat Dönemi Cizye Defterlerine Göre Sivas Şehrinde Ermeni Nüfusun Mesleki Yapılanması”. C.Ü. İktisadi ve İdari Bilimler Dergisi 17/2 (2016) 47-66.

Şener A. (1980). Tanzimat Dönemi Osmanlı Vergi Sistemi. Ankara 1990.

Tan S. (2010). 17 No'lu Antalya Şer'iyye Sicili'nin Transkripsiyonu ve Değerlendirilmesi 1297-1300 (M. 1879-1883). Yayımlanmamış Yüksek Lisans Tezi. Akdeniz Üniversitesi, Antalya 2010.

Tanrısever R. (2007). 12 No'lu Antalya Şer'iyye Sicili Defterine Göre 1862-1864 Ylllarn Arasinda Antalya Şehrinin İdarî ve Sosyo-Ekonomik Durumu. Yayımlanmamış Yüksek Lisans Tezi. Akdeniz Üniversitesi, Antalya 2007.

Taşbaş E. (2007). 15 No'lu Antalya Şer 'iyye Sicili Defterine Göre 1866-1867 Yulları Arasinda Antalya Şehrinin İdarî ve Sosyo-Ekonomik Durumu. Yayımlanmamış Yüksek Lisans Tezi. Akdeniz Üniversitesi, Antalya 2007.

Turan O. (2010). Selçuklular Zamanında Türkiye. İstanbul 2010.

Yörük D. (2013). "H.1259/ M.1843 Tarihli Cizye Defterlerine Göre Kayseri'de Rum ve Ermeniler”. Turkish Studies 8/11 (2013) 439-466.

Arşiv Belgeleri (Başbakanlık Osmanlı Arşiv Belgeleri)

BOA., KK.d., 3899.

BOA., ML.VRD.CMH.d., 171.

BOA., ML.VRD.CMH.d., 682.

BOA., ML.VRD.CMH.d., 733.

BOA., ML.VRD.CMH.d., 926.

BOA., ML.VRD.CMH.d., 1127

BOA., ML.VRD.CMH.d., 1251.

BOA., ML.VRD.CMH.d., 1346.

BOA., NFS.d., 3205.

BOA., NFS.d., 3206. 